\title{
Reassessing Shamanism and Animism in the Art and Archaeology of Ancient Mesoamerica
}

\author{
Eleanor Harrison-Buck ${ }^{1, *}$ and David A. Freidel ${ }^{2}$ \\ 1 Department of Anthropology, University of New Hampshire, Durham, NH 03824, USA \\ 2 Department of Anthropology, Washington University, St. Louis, MO 63105, USA; dfreidel@wustl.edu \\ * Correspondence: e.harrison-buck@unh.edu
}

Citation: Harrison-Buck, Eleanor, and David A. Freidel. 2021.

Reassessing Shamanism and Animism in the Art and Archaeology of Ancient Mesoamerica. Religions 12: 394. https://doi.org/10.3390/ rel12060394

Academic Editors: Max Carocci and Robert J. Wallis

Received: 6 March 2021

Accepted: 17 May 2021

Published: 28 May 2021

Publisher's Note: MDPI stays neutral with regard to jurisdictional claims in published maps and institutional affiliations.

Copyright: (c) 2021 by the authors. Licensee MDPI, Basel, Switzerland. This article is an open access article distributed under the terms and conditions of the Creative Commons Attribution (CC BY) license (https:// creativecommons.org/licenses/by/ $4.0 /)$.

\begin{abstract}
Shamanism and animism have proven to be useful cross-cultural analytical tools for anthropology, particularly in religious studies. However, both concepts root in reductionist, social evolutionary theory and have been criticized for their vague and homogenizing rubric, an overly romanticized idealism, and the tendency to 'other' nonwestern peoples as ahistorical, apolitical, and irrational. The alternative has been a largely secular view of religion, favoring materialist processes of rationalization and "disenchantment." Like any cross-cultural frame of reference, such terms are only informative when explicitly defined in local contexts using specific case studies. Here, we consider shamanism and animism in terms of ethnographic and archaeological evidence from Mesoamerica. We trace the intellectual history of these concepts and reassess shamanism and animism from a relational or ontological perspective, concluding that these terms are best understood as distinct ways of knowing the world and acquiring knowledge. We examine specific archaeological examples of masked spirit impersonations, as well as mirrors and other reflective materials used in divination. We consider not only the productive and affective energies of these enchanted materials, but also the potentially dangerous, negative, or contested aspects of vital matter wielded in divinatory practices.
\end{abstract}

Keywords: Mesoamerica; art and archaeology; shamanism; animism; Indigenous ontology; relational theory; divination; spirit impersonation; material agency

\section{Introduction}

Placing greater emphasis on Indigenous ontologies and relational epistemologies opens up fresh perspectives on some age-old concepts in anthropology, which include shamanism and animism. These new perspectives are reshaping studies of shamanism and animism in art and archaeology, as the contributions in this Special Issue attest. Shamanic practice and animism have long been conceived as closely knit concepts in anthropology (Tylor [1871] 1958, pp. 241-42; see also Furst 1976). While they have proven to be useful cross-cultural analytical tools over the years, particularly in religious studies, both concepts root in reductionist (neo)evolutionary theory and have been criticized for their vague and homogenizing rubric, an overly romanticized idealism, and the tendency to 'other' Indigenous peoples as ahistorical, apolitical, and irrational (Klein et al. 2002; Van Dyke 2018). The alternative has been a largely secular view of religion, favoring materialist processes of rationalization and "disenchantment" (Fowles 2013). We trace the intellectual trends of shamanism, and its close relative animism, and how these concepts have been recently reclaimed by so-called relational or ontological archaeologists. This scholarship offers new and productive ways for using these comparative analytical terms in religious studies in anthropology and archaeology (for some examples see Abadia and Porr 2021; Alberti and Bray 2009; Alberti and Marshall 2009; Bird-David 1999; Brown and Walker 2008; Erazo and Jarrett 2017; Kosiba 2020; Gheorghiu et al. 2017; Harrison-Buck 2015; Harvey 2006; Porr and Bell 2012; Pharo 2011).

Current ontological studies of animism depart from Tylor's ([1871] 1958) traditional definition as "the belief in spiritual beings" to include a world that "is found to be, 
and treated as, a community of persons not all of whom are human" (Harvey 2006, p. 11). Brown and Walker (2008, p. 297) define animacy as "an ontology in which objects and other nonhuman beings possess souls, life-force and qualities of personhood." Some scholars have incorporated this "new animism" in their discussions of shamanism (Wallis 2009, 2013a, 2013b). Yet, most scholarship still leans heavily on Mircea Eliade's well-known Siberian model where he defines shamanism as "an individual who has received power to cure and divine direct from supernatural beings through dreams, visions, or spirit possessions" (Eliade 1964, p. 48). The distinguishing features most often cited is the shaman's "use of altered states of consciousness and the emphasis on becoming a 'nonhuman' spirit agent" (VanPool 2009, p. 178). Most religious scholarship, however, remains dissatisfied with the "diverse, indistinct, and often contradictory ways" that shamanism is applied with some advocating the need to redefine or reconstruct the term (Pharo 2011, p. 9), while others think it should be abandoned altogether (Klein et al. 2002).

Astor-Aguilera (2010, p. 9) observes that "[m]any studies of Mesoamerican religion are partly based on the assumption that past and present Mesoamerican ritual practices are centered on the assumed archaic religion of shamanism." We agree that trying to define a Mesoamerican "religion" based on the traditional pan-Asian definitions of shamanism and "its associated ideological rhetoric" is problematic and risks diminishing or obscuring Indigenous cosmological worldviews (Astor-Aguilera 2010, p. 15). We suggest that a relational ontological approach offers a more productive way forward. From this perspective, shamanism and animism are not viewed as static, prefigured religious structures or as a set of religious beliefs but are understood as an alternative means of acquiring knowledge and as a distinct way of knowing the world. Anthropologists often contrast a relational ontology with a modernist substance ontology, which relies on a Western objectivist, scientific paradigm and taxonomic classification for understanding the world (Alberti 2016, p. 166). A relational ontology is a distinct way of being in the world where one acquires knowledge through a two-way relationship with the environment, rather than being separate from it. From this perspective, culture and nature are conflated, often along with other so-called modernist Cartesian divides, such as human-animal, subject-object, animate-inanimate (Watts 2013, p. 1).

We argue that a relational ontological approach addresses many of the criticisms regarding the inconsistencies and contradictions in how we use the terms shamanism and animism cross-culturally and upends the ahistorical and apolitical rhetoric toward 'Otherness' rooted in colonialism, which plagued earlier anthropological approaches (Klein et al. 2002, p. 384). In this way, shamanism and animism can continue to serve as useful cross-cultural terms without being essentialized as a "primitive" religious structure or belief system and universalized in such a way that reinforces derogatory images of Indigenous peoples (see Bird-David 1999, p. 68). Like any cross-cultural frame of reference, such terms are only informative when explicitly defined in local contexts using specific case studies (Atkinson 1992). Here, we reassess shamanism and animism as an alternative means of acquiring knowledge and knowing the world, specifically within ancient Mesoamerica - an area that encompasses Mexico, Guatemala, Belize, Honduras and parts of El Salvador (Figure 1). In this study, we rely on ethnographic and archaeological data as well as ancient iconography and writing systems. Together, these sources greatly inform our understanding of Indigenous perspectives and practices. We focus specifically on imagery showing masked individuals temporarily impersonating spirits and examine archaeological examples of mirrors and other reflective materials used in divination, which are found at sites across Mesoamerica. Both epigraphic and ethnographic data from Mesoamerica are explicit in clarifying that these materials (mirrors and masks) did not serve as an intermediary but conferred temporary housing for the animate co-essence itself. In the case of masked shamans, they acquired knowledge through animistic impersonation that gave personhood to the more-than-human spirit agent where the shaman served as the object or receptacle that temporarily housed this communicating co-essence or life force (Stone 1991). Likewise, mirrors and other shiny materials also served as "communicating objects" for 
animate spirits, as discussed further below (see also Astor-Aguilera 2010, p. 238; Blainey 2007, 2016; Healy and Blainey 2011; Love 2012, pp. 30-35; Molesky-Poz 2006, pp. 65-66).

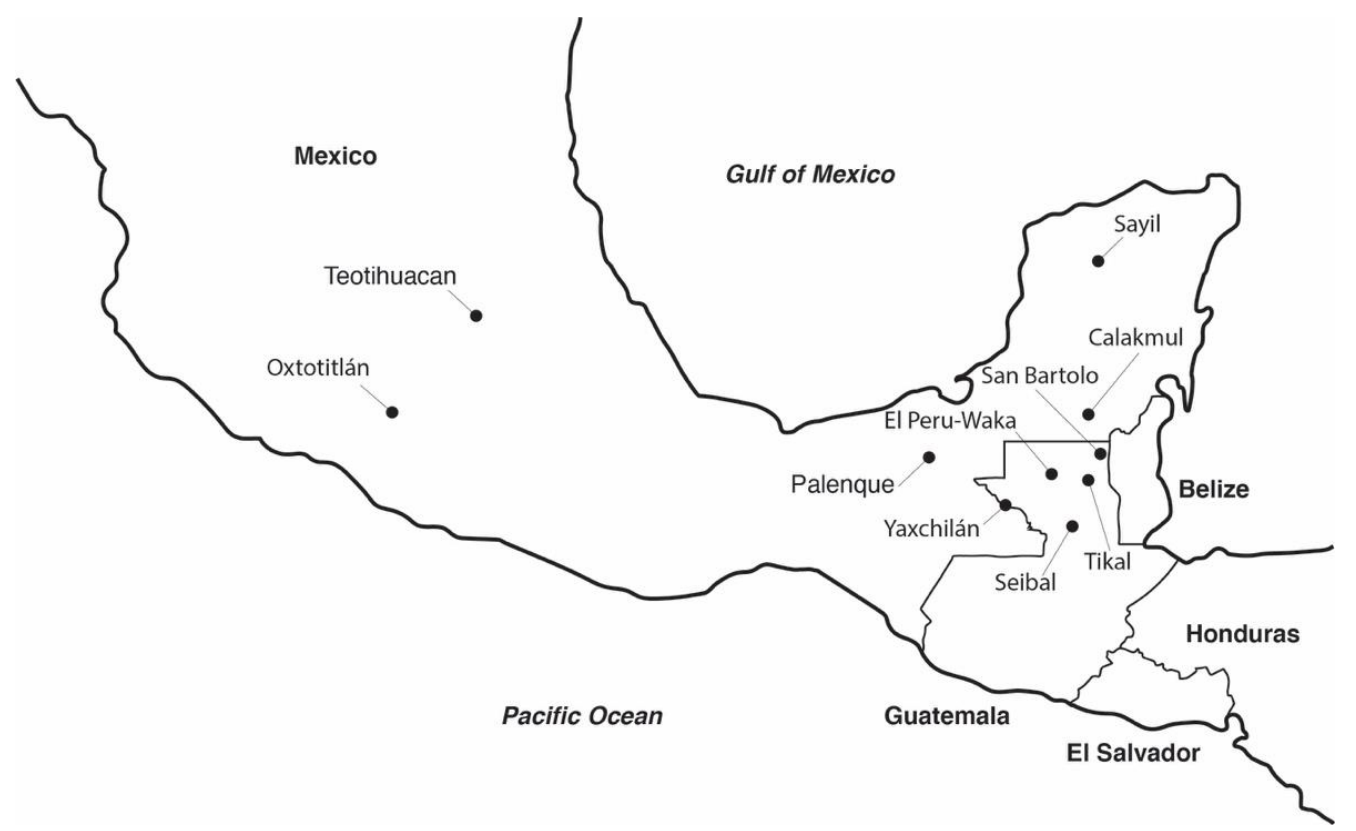

Figure 1. Map showing sites mentioned in text (drawn by K. Titus).

In this study of Mesoamerican art and archaeology, we aim to show how both the shaman and their objects were actively constituted as relational beings through divinatory practice. In this way, Mesoamerican peoples did not see the world in terms of a sharp distinction between active (human) subject and passive (nonhuman) object; both humans and materials had the potential for animate more-than-human behavior and could serve as temporary bodies for powerful spirits. Ethnographic data suggest that in a Mesoamerican relational ontology magical or enchanted spirits could assume productive and affective energies when engaged in reciprocal two-way relations, but that the one-sided control of nonhumans, such as wind spirits, constituted sorcery and could bring about illness and other potentially dangerous, negative, or contested aspects of vitality (Astor-Aguilera 2010, p. 169). As such, our study of shamanism and animism in the context of Mesoamerica considers how impersonation and divinatory practice were not merely benign ways of knowing and acquiring knowledge but had the potential to leverage power in both positive and negative ways.

\section{Tracing the Intellectual History}

Shamanism and animism have a long history as analytical tools for cross-cultural comparison in anthropology, initially developed to describe the earliest of Indigenous religions (Castrén 1853; Durkheim [1912] 1961; Tylor [1871] 1958). Late nineteenth-century ethnographers, like Mallery (1893, pp. 191-92, emphasis ours), suggested that the shaman "pretends to control, by incantations and ceremonies, the evil spirits to whom death, sickness, and other misfortunes are ascribed." Likewise, nineteenth-century anthropologists, like Tylor ([1871] 1958) defined the term animism as "the general belief in spiritual beings" (1958, p. 10), but concluded that it was based on falsehoods and "superstitious folly" (ibid. 5). In these earlier works, it was made clear that shamanism and animism were merely a projection of the "savage" imagination and were classified as "primitive" religious structures. As Wilkinson (2017, p. 289) observes, because such terms were primarily developed out of Victorian thought, they present largely derogatory views of Indigenous cultures that rest on social evolutionary paradigms, which were subsequently discredited.

It was not until the 1960s that these terms saw a resurgence in Americanist Anthropology and were increasingly embraced in Mesoamerican studies of art and archaeology 
(e.g., Furst 1965, 1968, 1976, 1994). This shift coincided with growing popular interests in alternative spiritual philosophies and psychedelics. Yet, even before this time, as early as the beginning of the twentieth century, the terms "shamanism" and "animism" were being employed in ethnographic research in Mesoamerica (La Farge 1947; La Farge and Byers 1931; Madsen 1955; Oakes 1951; Redfield and Villa Rojas [1934] 1964; Vogt 1966, 1976). In reviewing these and other ethnographic studies, Tedlock (1982, p. 50) concluded that the majority of the Indigenous communities from across Mesoamerica shared the requisite traits of "shamanism" as traditionally defined by Eliade (1964), which include direct communication between the diviner and the spirit agent through dreams, visions, and spirit possession. Her study countered earlier work by Madsen (1955) who suggested that shamanism was restricted to areas of central Mexico.

Toward the end of the twentieth century, Mesoamerican archaeological studies began regularly employing "shamanism" as a term and relied heavily on the wealth of ethnographic comparisons, alongside studies of archaeological and epigraphic data, most especially for the Maya region (Boyd 1996; Freidel et al. 1993; Kappelman 2001; Markman and Markman 1989; Reilly 1989, 1995; Schele and Freidel 1990; Schele and Miller 1986; Tate 1999). Yet, by the turn of the twenty-first century, the term was once again drawing sharp criticism in studies of Mesoamerican art and archaeology. Klein et al. (2002) have been among the most vocal critics of shamanism, in particular. These scholars conclude that studies interpreted through a lens of shamanism show "an idealist aversion to materialist explanations of human behavior" (Klein et al. 2002, p. 383). From this materialist (Marxist) perspective, shamanism and animism are presented as expressions of a secular, false religious ideology and are thought to merely mask political and economic agendas in early societies (Klein et al. 2002, pp. 387, 405-6).

Over the years, scholars have found that to engage seriously with shamanism and animism has presented an "unsettling challenge" and there has been a clear reluctance in archaeology (even among phenomenologists) "to step beyond a rational materialist standpoint" (Wallis 2009, p. 51). Following the publication of Klein et al.'s (2002) article, there have been only a select few publications that have continued to explore shamanism as a comparative framework in ancient Mesoamerica (e.g., Blainey 2016; Healy and Blainey 2011; Stone 2014). Much of the recent scholarship has side-stepped the issue (in the ancient Maya case, see Martin 2020, p. 144) or has been a rebuke of shamanic interpretations (e.g., Beekman 2020; Stuart 2021; Zender 2004) or has been isolated to areas north or south of Mesoamerica (Stone 2011; VanPool 2003, 2009; VanPool and VanPool 2007). The concept of animism, on the other hand, has been more seriously problematized in recent studies of complex societies in ancient Mesoamerica. Current studies have advanced more sophisticated and sensitive theoretical treatment, attempting to take Indigenous theory seriously (e.g., Brown and Emery 2008; Halperin 2018; Harrison-Buck 2012a, 2012b, 2015, 2020; Harrison-Buck et al. 2018; Hendon 2010, 2012, 2018; Houston 2014; Jackson 2017, 2019; Joyce and Barber 2015; Kosiba et al. 2020; Kovacevich 2014, 2017; Looper 2018, among others).

Unlike animism, we suggest that serious consideration of shamanism in studies of complex societies have been stymied in part by the perpetuation of a false dichotomization that separates the shaman from the role of the priest and delineates these roles in terms of separate kinds of religious structures (e.g., Hayden 2003; Vadala 2014; Zender 2004). “As intuitive as it may seem ... . shamans and priests are not appropriate archetypes and do not reflect dichotomous or essentialist 'types' in the sense that they are immutable states wholly distinct from one another" (VanPool 2009, p. 178; see also Pharo 2011). The strength of VanPool's (2009, Figure 1) argument is her conclusion that the shaman and the priest are anthropological constructs that do not reflect discrete roles in a given society. However, her explanatory model falls back on a social evolutionary paradigm, where "religious traits [of shamans and priests] tend to correspond with one another as the level of cultural complexity shifts" (VanPool 2009, p. 178). This trajectory is common in studies of prehistoric religion, where shamanism is presented as a "primordial religion" that is an apolitical formulation 
that "[sits] upon a kind of moral pedestal" whereas the priesthood is an institutionalized religion that has "[become] increasingly political, destructive, ideological, and oppressive" (Fowles 2013, p. 33).

That a continuum from shaman to priest represents a shift from lesser to greater societal complexity is a remnant of Durkheimian evolutionary theory. This reductionist paradigm, rooting in Victorian thought, conceives of shamanism as a "primitive" religious structure most often associated with simple hunter-gatherer societies that was ultimately replaced by an institutionalized 'priesthood' once agriculture was adopted and more complex agrarian societies developed (e.g., Vadala 2014). Even today, shamanism is still presented as "performative and imagistic rites ... whereas liturgical and doctrinal modes are characteristic of hierarchical polities and institutionalized religions" (Swenson 2015, p. 340; see also Fowles 2013, pp. 30-31). In this vein, scholars typically describe the shaman as attending to the household or interpersonal sphere and serving as healers and midwives, whereas the priest is responsible for the maintenance of a community temple, sanctuary, or shrine, in charge of overseeing calendrical rites and large-scale public ceremonies (Zender 2004, p. 39). Findings in Mesoamerican ethnography have shown that these are false divisions. In Tedlock's (1982, p. 47) study of 'Daykeepers' (ajq'ijab') and 'mother-fathers' (chuchkajaw) among the Momoestecan highland Maya, she concludes: "If one adopted the analytical method cultural anthropologists use for separating shaman and priests, in which the priest serves as an intermediary between man and gods while the shaman directly possesses (or is possessed by) supernatural powers in the realm of divination and curing, one would have to refer to all Momostecan Daykeepers and motherfathers as both priests and shamans." Her solution is to refer to them as 'priest-shamans.'

Despite the findings from ethnography and the concerted efforts to shake the "primitive" associations of shamanism (Pharo 2011, pp. 18-22), archaeologists studying complex state-level societies tend to systematically replace "shaman" with "priest" and describe Indigenous religion in terms of a formalized institution in line with other world religions (Wilkinson 2017, pp. 290-91; Pharo 2011, p. 18; VanPool 2009, pp. 178-80). Wilkinson (2017, p. 290) observes that terms like shamanism or animism are generally not characterized by proper nouns like the names used to designate world religions, such as Christianity, Judaism, Buddhism, and so forth. Pharo (2011, p. 15) argues that these terms would be less problematic if they were viewed as similar "ideal types" (sensu Weber 1969) that strictly served as general comparative concepts of Indigenous theology, rather than discrete categories "with an actual empirical realization." From this perspective shamanism and animism "[are] not a description of reality" (Weber 1969, p. 90 cited in Pharo 2011, p. 15), but still remain firmly within an Indigenous religious structure and system of beliefs identifiable by various transhistorical types of shared traits, such as altered states of consciousness (ASC), divination, and curing, among other variables of ritual practice and paraphernalia ( $a$ la Eliade 1964; see also VanPool 2009 for further discussion). Following Eliade (1964, p. 333), some scholars like Blainey (2016, p. 181), who describes these as "religious [categories] of shamanism," has gone so far as to argue that, based on their widespread appearance in Mesoamerica, "that some elements of Siberian shamanism accompanied pre-Columbian migrations across the Bering land bridge."

Rather than representing a vast diffusion stemming from Siberia, we would agree with Pharo that shamanism and animism are better understood as general comparative anthropological concepts and it is in this way that we employ them here. However, in order to move shamanism and animism beyond their firm lodging in the "savage slot" of anthropology, we suggest that divorcing these terms from an ontological reality is not the answer. On the contrary, we advocate moving beyond the Western category of "religious theology" and reinforce the ontological commitments expressed in shamanism and animism - as ongoing relations with the environment that Indigenous peoples describe as distinct ways of knowing the world and as alternative means of acquiring knowledge. Below, we take a closer look at how shamanism and animism have been applied as anthro- 
pological constructs in the context of contemporary and ancient Indigenous Mesoamerica and cross-examine these ideas in terms of a relational ontological perspective.

\section{Reassessing Shamanism and Animism as a Relational Ontology}

Using broadly shared cross-cultural terms, like shamanism and animism, helps anthropologists to communicate with one another alternative epistemologies and ontologies that differ from a Western means of acquiring knowledge and knowing the world. Our approach to shamanism and animism relies heavily on Indigenous philosophies gleaned from epigraphy, archaeology, and ethnography from across Mesoamerica. Such anthropology-inspired ontological approaches are variously referred to as "social ontologies" (Alberti 2016, p. 164) or "relations of epistemologies" (Harris 2021a, pp. 16-17). Scholars have contrasted this social ontological approach with the so-called "metaphysical" approach to ontological archaeology, sometimes referred to as the New Materialisms (Alberti 2016). Such "relations of metaphysics" emphasize the role of emergent material relations that are always in a process of becoming (Harris 2021a, p. 20). This approach largely rejects anthropological theory and "the social" in favor of the fundamental nature of emergent matter (Alberti 2016, p. 165). The New Materialists are mostly concerned with "how the world operates regardless of what people think about it" (Harris 2021b, p. 17). A strength of the metaphysical approach is its attention to the complex "meshwork" of vibrant matter (bodies, soil, water, shells, and countless other phenomena) as emergent and continually changing, reinforcing an ontological reality that is not anthropocentric, static, or prefigured (see Bennett 2010). Yet, as Alberti (2016, p. 171) notes, the "painstaking work of developing new archaeological metaphysics on the basis of an alternative Western intellectual tradition brings us no closer to grappling with the ontological difference presented to us anthropologically."

What most "metaphysical archaeologists" have in common is their focus on European prehistory where the (mis)appropriation of Indigenous philosophies is an ethical concern that remains far from resolved (Harris 2021b, p. 71; for a fuller critique see Todd 2016). A social ontological approach is more often applied in the Americas where archaeologists have ready access to ethnographies centered around descendant communities who offer a wealth of Indigenous knowledge. Social ontologies that rely heavily on Indigenous epistemologies often are considered part of a larger decolonizing effort in the field of anthropology, challenging traditional Western authorized accounts of the past (see Atalay 2006, 2008; Watkins 2000). Taking on board an Indigenous ontological project involves a shift in method and theory-building that serves to democratize knowledge production, moving toward a more ethically-grounded archaeological practice (Montgomery 2021, p. 55). An Indigenous ontological approach does not mean doing away with science, but rather, stresses a blended approach that Atalay (2012, p. 27) and the Anishinaabe refer to as 'braiding knowledge' to "create space for multiple ways of knowing that complement each other" (Atalay 2020, p. 1). Instead of Indigenous epistemologies serving as supporting evidence for Western theoretical frameworks, Indigenous knowledge itself serves as theory (Laluk 2017, pp. 100-2; Montgomery 2021, p. 55).

Indigenous ontologies and philosophies differ across the Americas. However, one generally shared aspect is the presence of an animate, other-than-human world where "knowledge is constantly changing, experiential, and contextual" (Montgomery 2021, p. 59). As the Indigenous scholar Todd (2016) observes, even if it is not explicitly stated (which it often is not), most anthropological theory regarding relational ontologies derives from Indigenous knowledge about how the world operates. For instance, our understanding of a relational ontology in Mesoamerica comes from observations of contemporary Indigenous groups, such as the Highland Maya who express their ontological way of being as a two-way relationship of mutual care and interdependency based on their positioning and activity in-the-world (Molesky-Poz 2006). Elsewhere, Nurit Bird-David (1999, pp. 68-69) has made similar ethnographic observations among Indigenous groups in South Asia, which she calls "relatedness" and defines as "mutually responsive changes in things in-the-world and at the same time in themselves." Bird-David (1999) suggests that this 
distinct way of knowing the world as a two-way conversation of "responsive relatedness" is linked with an animistic epistemology, but the concept is also helpful for conceptualizing an alternative means of acquiring knowledge that ethnographers have recorded and described cross-culturally as shamanism. This distinct way of knowing the world for many Indigenous peoples is achieved through bodily experience and two-way engagement with one's environment, which, in a relational world, is both animate and inanimate, human and other-than-human.

People enmeshed in a relational ontology "turned, not to theological pronouncements and speculations to verify their ideas, but to experience-to what can be seen, touched, heard, and smelled" (Furst 1997, pp. 2-3). This distinct way of knowing the world and acquiring knowledge aligns with what we know from studies across Mesoamerica, where ethnographers record how trained specialists whom they describe as "shamans" seek answers through sensory experience (Furst 1997; Molesky-Poz 2006; Stross 1998; Tedlock 1982). For instance, the contemporary highland Maya ajq'ijab' ("Daykeeper") acquire knowledge and "answerability" by reading the movements in their bodies (MoleskyPoz 2006; Tedlock 1982). Diviner's are trained to understand how to read signals called the cacha' uquiqu'el or "speaking of the blood" (Tedlock 1982, pp. 138-39). Pulsing in different parts of the body points to various concerns for a specific gender and can indicate different moments in time (past, present or future events) and space (in terms of the four-directional universe (Tedlock 1982, pp. 140-41, Figure 26)). In other words, the mind or 'interpreting act' of the diviner is intimately bound up and inextricably linked with their bodily feelings and positionality in the landscape.

This way of knowing and acquiring knowledge as a bodily-felt process has been recorded in a range of archaeological and epigraphic contexts (Freidel et al. 1993; HarrisonBuck 2012a, 2015; Houston et al. 2006; Houston and Taube 2000; Lopez Austin 1988). The ancient Maya, in particular, had signs in their art and writing that expressed this complex "synesthesia" which simultaneously communicated in visual, graphic, and permanent forms the affective experience of sound, smell and sight (Houston and Taube 2000; Houston et al. 2006, pp. 136-39). According to Houston and Taube (2000, p. 289), such affective relations were expressed in "synesthetic codes," such as spirals, scrolls and volutes emanating from eyes and mouths of human and nonhuman beings, which not only communicate a multi-sensory experience but also are embodiments of the animate spirit or co-essence living within (Houston et al. 2006, pp. 136-37; see also Houston 2014). Among the ancient Maya, for instance, the eye is not just tied with vision but is agentive and the power of sight is procreative, having the capability of affecting and changing things in the world and "[establishing] communion between internal will and external result" (Houston et al. 2006, p. 167).

Elsewhere, we describe this meta-sensory form of embodied cognition as "conversively co-creative" (Harrison-Buck 2018, p. 274)—an approach that stems from ethnographic observations of Indigenous storytelling (see Brill de Ramírez 2007). In the study presented below, we consider shamanism and animism as a relational ontology that is conversively cocreative and entails both discursive (abstract cognition) and non-discursive (bodily) ways of knowing the world and acquiring knowledge. From this perspective, materialism and idealism are viewed as a continuum of relational fields where both humans and nonhumans are potentially animate agents (see Harrison-Buck and Hendon 2018 for further discussion).

\section{Shamans as Animating Impersonators in Mesoamerica}

In ancient Mesoamerican art, both human and nonhuman beings are regularly depicted in the same scene communicating with one another. These images suggest that certain humans were capable of transcending the nonhuman spirit world and vice-versa. In some instances, humans are shown wearing costumes and masks of the divine, suggesting that they could temporarily become a divine being by impersonating them (Houston and Stuart 1996; Houston et al. 2006, pp. 270-74; Pharo 2007, p. 61; Stone 1991). While Klein (1986, p. 159) argues that the mask and costume "constituted a false reality [creat- 
ing] an image or approximation rather than constituting an actual being," Stone (1991, p. 194) emphasizes the human agency of the masked impersonator who is able to "interject their presence in supernatural affairs." In other words, for Stone these were two-way engagements that were mutually empowering since impersonation allows for a temporary harnessing of supernatural divinity. Stone (1991, pp. 194-95) goes so far as to say that the development of "impersonation cults" in Mesoamerica was directly linked to the rise of complex state-level societies and a system of divine kingship, beginning with the Gulf Coast Olmec by Early Preclassic times (ca. 1100-900 BCE).

Throughout the Olmec era, there are many examples of masked animal impersonation, often featuring jaguarian or avian counterparts, interpreted as evidence of shamanic shape-shifting and transformation (see contributions in Coe 1995). A famous example is a mural from the Oxtotitlan cave in highland Guerrero, Mexico, that depicts a masked royal impersonation of a raptor (Figure 2a (Grove 1970)). The Olmec ruler enthroned at Oxtotitlan reveals his human face, X-ray fashion, behind his mask. It is the face that contains essential spiritual qualities in ancient Mesoamerica (Houston and Stuart 1996), and it is probably for this reason that such portraits show masked individuals as X-ray depictions, emphasizing revelation over concealment. Another example of this is the standard royal helmet crown mask, commonly found in Olmec, Isthmian, and Mayan art, being worn by Preclassic rulers (Figure 2b (Taube 1996, Figures 18 and 19)). The trefoil headband jewel crowning the royal helmet is interpreted as maize foliage, suggesting plant impersonation (Taube 1996). One famous example is seen in the Late Preclassic (West Wall) mural of the Pinturas Building at the Maya site of San Bartolo in Guatemala (Taube et al. 2010, color supplement). Other examples of the trefoil motif denoting maize vegetation are found in Preclassic Oaxaca (Barber and Sánchez 2012, p. 17). Here, carved masks dating to the Preclassic period also have been found depicting distinctive elements of Cociyo, the Zapotec rain deity. In wearing such masks, an impersonator served as a receptacle for this "vital force of agricultural fertility, responsible for casting lightning bolts through the sky, splitting apart the clouds and allowing rain to fall" (Brzezinski et al. 2017, p. 517). The presence of numerous Preclassic examples suggest that masked impersonation of animals, maize plants, rain, and other life-giving phenomena was a central component of rulership beginning with the earliest kings in Mesoamerica.

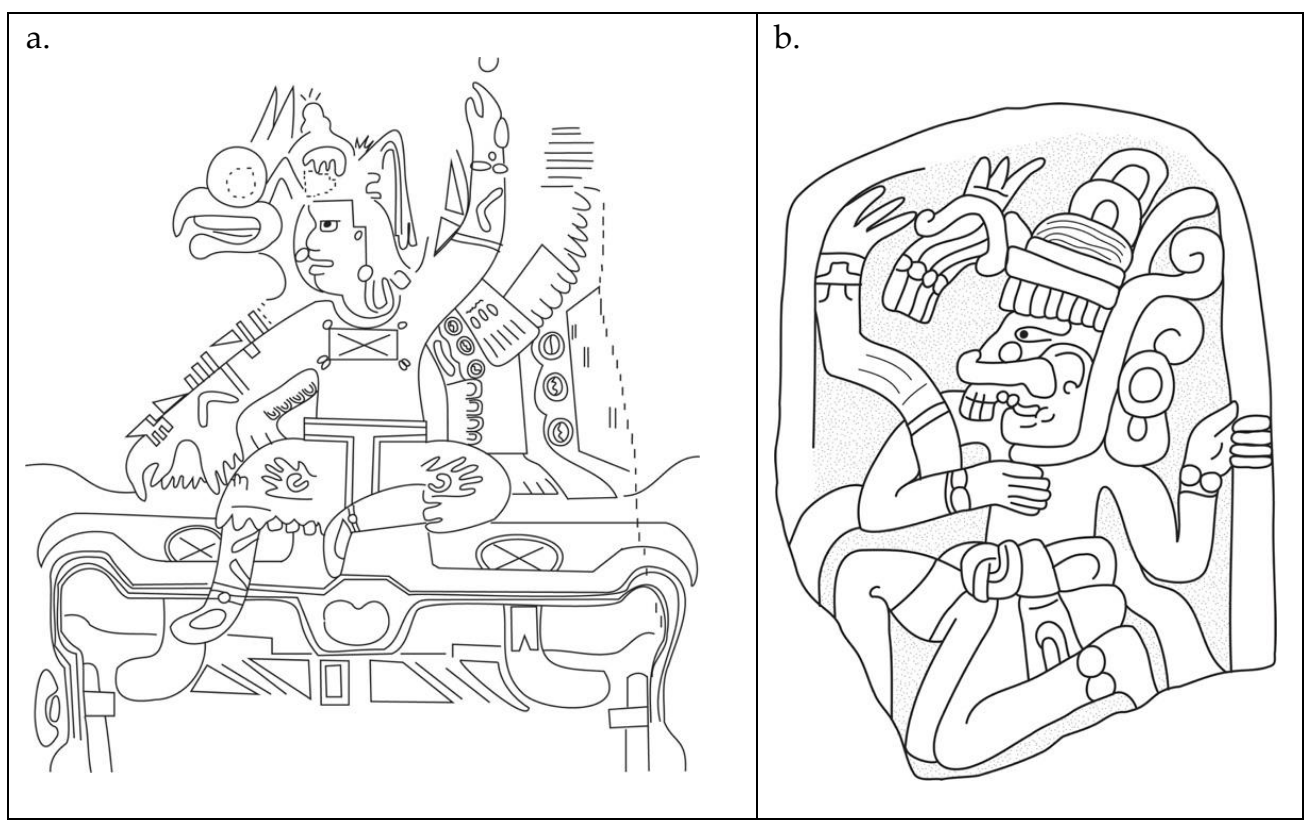

Figure 2. (a) Preclassic Olmec-style mural from the Oxtotitlan cave in highland Guerrero, Mexico (adapted from Grove 1970, redrawn by K. Titus); (b) Classic period Isthmian Maize God impersonator wearing a version of royal helmet mask with trefoil jewel (after Taube 1996, Figure 19a, redrawn by K. Titus). 
Masked artistic conceit was employed throughout Mesoamerican history. For instance, Classic Maya rulers more than a millennium later are shown masked in the form of certain animals, maize plants, rain, and other personified forces (Schele and Freidel 1990, pp. 28485). One example on a carved monument from the site of Yaxchilan shows a ruler masked as the powerful storm god Chaak (Figure 3). Another Classic Maya example on an incised jaguar bone from the Dallas Museum of Art depicts an Old God ("God N") lifting the full helmet mask onto a young lord (Figure 4). Here the main upper divine image on that helmet is the Principal Bird Deity, solar bird avatar of Itzamnaaj who is often characterized as the principal "shaman-priest" and "creator" of the cosmos in both Postclassic Maya codices and Classic Maya imagery and epigraphy (Barrera Vasquez 1980, p. 272; Freidel et al. 1993, pp. 47, 210-13, 412, Note 19; Kappelman 2004, p. 114; see also discussion in Martin 2015).

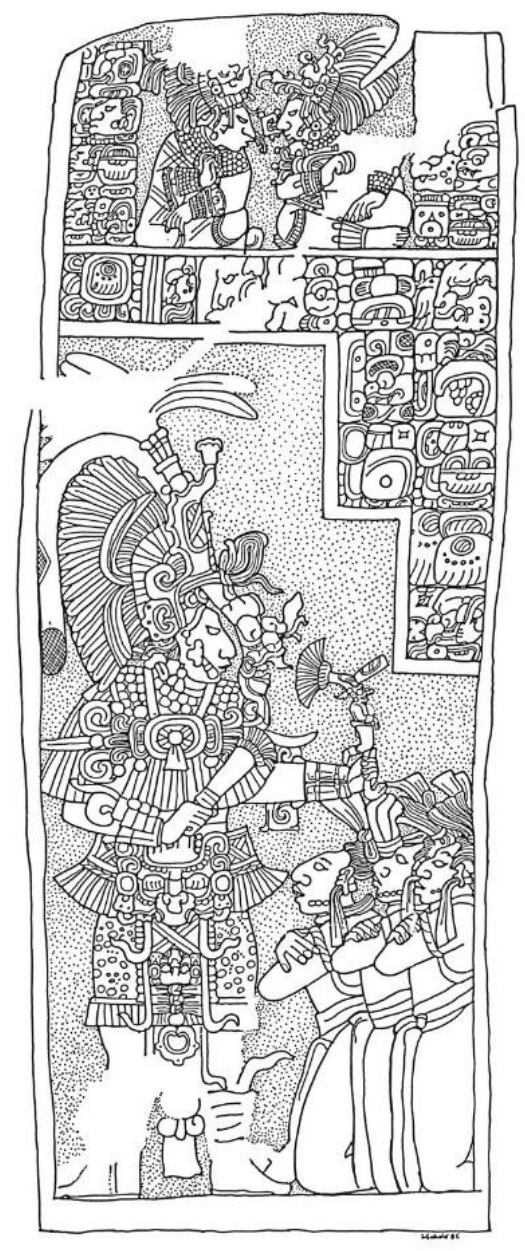

Figure 3. Stela 11 from the Maya site of Yaxchilan showing a ruler wearing the mask of the rain deity Chaak (courtesy of the Linda Schele Drawings Collection, (c) 2000 David Schele). 


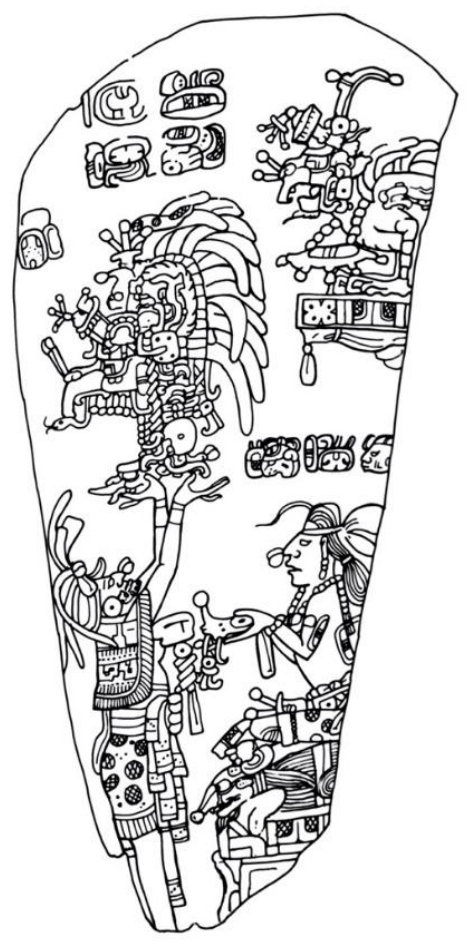

Figure 4. A Classic incised jaguar bone in the Dallas Museum of Art (courtesy of the Linda Schele Drawings Collection, (C) 2000 David Schele).

Depending on the context, different aspects of Itzamnaaj were impersonated by the ancient Maya (Martin 2015), ranging from the sun-filled Kinich Ahau to his night sun counterpart, the so-called Jaguar God of the Underworld (JGU). The latter was often called in to deal explicitly with death rituals that took place at night and involved firedrilling (hoch' $\left.k^{\prime} a k^{\prime}\right)$, incense-burning, and fire-entering rituals performed in the tombs of ancestors (Stuart 1998, pp. 402-9). For example, Altar 5 from Tikal (Figure 5) depicts an exhumed female ancestor whose long bones and skull are shown with two kneeling JGU impersonators who hold fire-drilling staffs and have jaguar facial markings (Stuart 1998, pp. 407-8). Impersonators of JGU, equated with the role of yajawk'ahk' ("Lord of Fire" or "Fire's Vassal") conjured the night sun through objects, such as fire, smoke, and mirrors (Martin 2020, p. 93; Stuart 2005, p. 123-25; see Zender's (2004, pp. 195-210) more lengthy consideration of the role of the yajawk'ahk' who he prefers to characterize as a "priest" rather than "shaman" probably for some of the reasons discussed earlier).

Censing and fire-drilling is also of central importance to the Aztecs and, like the Maya JGU, the Aztec Black Tezcatlipoca is closely associated with jaguars, smoke, and mirrors, specifically made of black obsidian (Saunders 2001). Notably, the Aztec Nahuatl "smoking mirror" glyph atl tlachinolli replaces the left foot of Tezcatlipoca (Saunders and Baquedano 2014, p. 4). Scholars describe Tezcatlipoca as "a truly shaman-like transformative figure" (Saunders and Baquedano 2014, p. 2; see also Saunders 1990, pp. 166-67). Referred to as Yohualli Ehecatl ("Night Wind"), Tezcatlipoca was much feared for he was considered "an inspirer of evil activities among sorcerers [and] also the origin of a number of illnesses, carried around by [the] 'airs of the night'" (Olivier 2014, p. 60). An example of a Tezcatlipoca mosaic skull mask fastened with long deerskin straps suggests it was worn on the body of a Tezcatlipoca impersonator, perhaps as a back ornament rather than as a facial mask (Figure 6). A human skull forms the base of this elaborate mask dating to the fifteenth-sixteenth century, decorated with alternating bands of bright blue turquoise and black lignite, white conch shell eye orbits, and mirror eyes made of polished iron pyrite (Klein 1986; McEwan et al. 2006). Coltman et al. (2020, pp. 346-47) note that human skulls with associated smoking mirrors mark one of the calendric names for Tezcatlipoca, translated as "1 Death." They illustrate how across Mesoamerica, during Postclassic times, skulls 
and smoking mirrors were intimately bound up with "images regarded as Tezcatlipoca or of his earthly impersonators" (Coltman et al. 2020, p. 346).

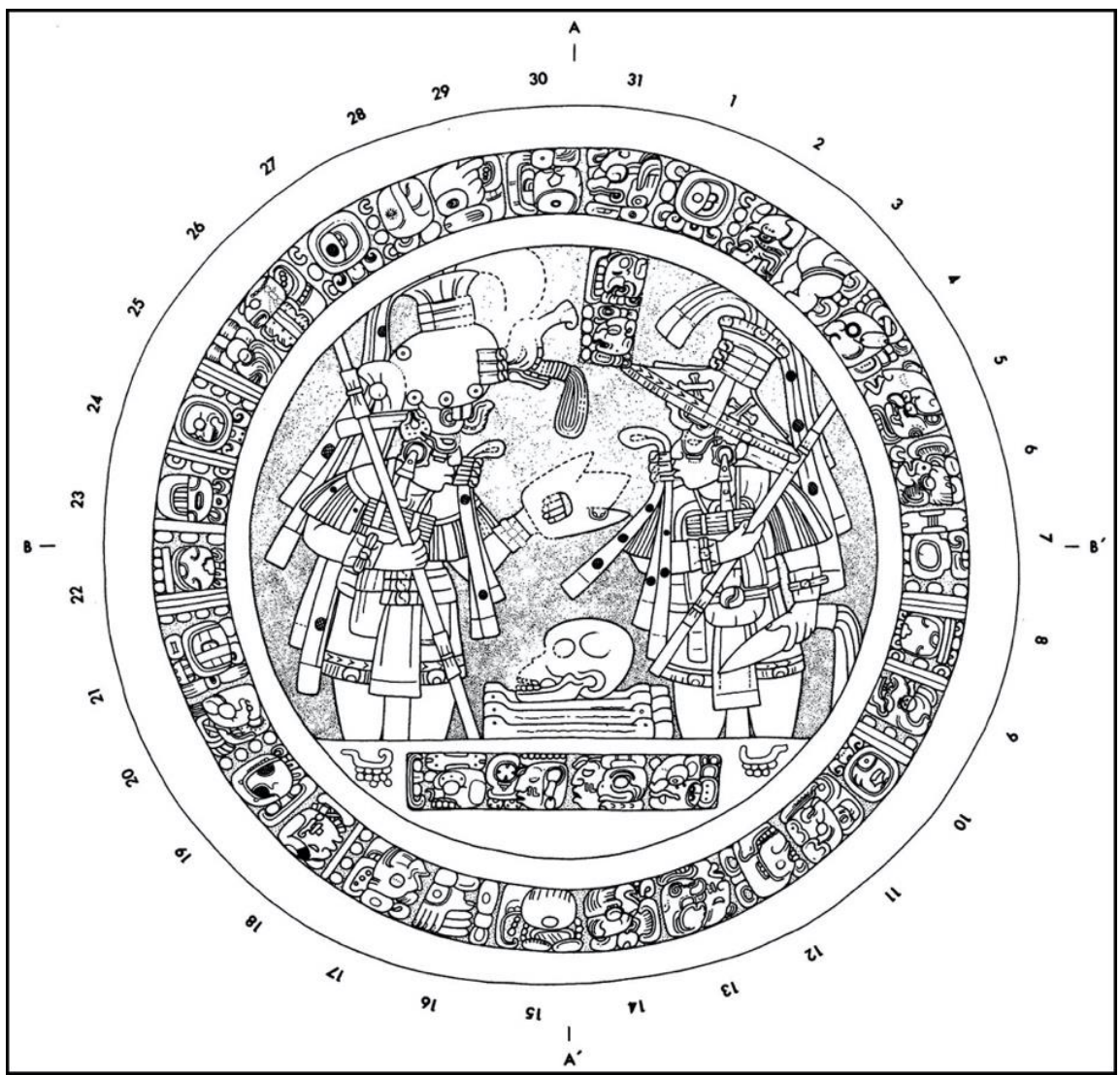

Figure 5. Altar 5 from Tikal (courtesy of the Linda Schele Drawings Collection, (c) 2000 David Schele).

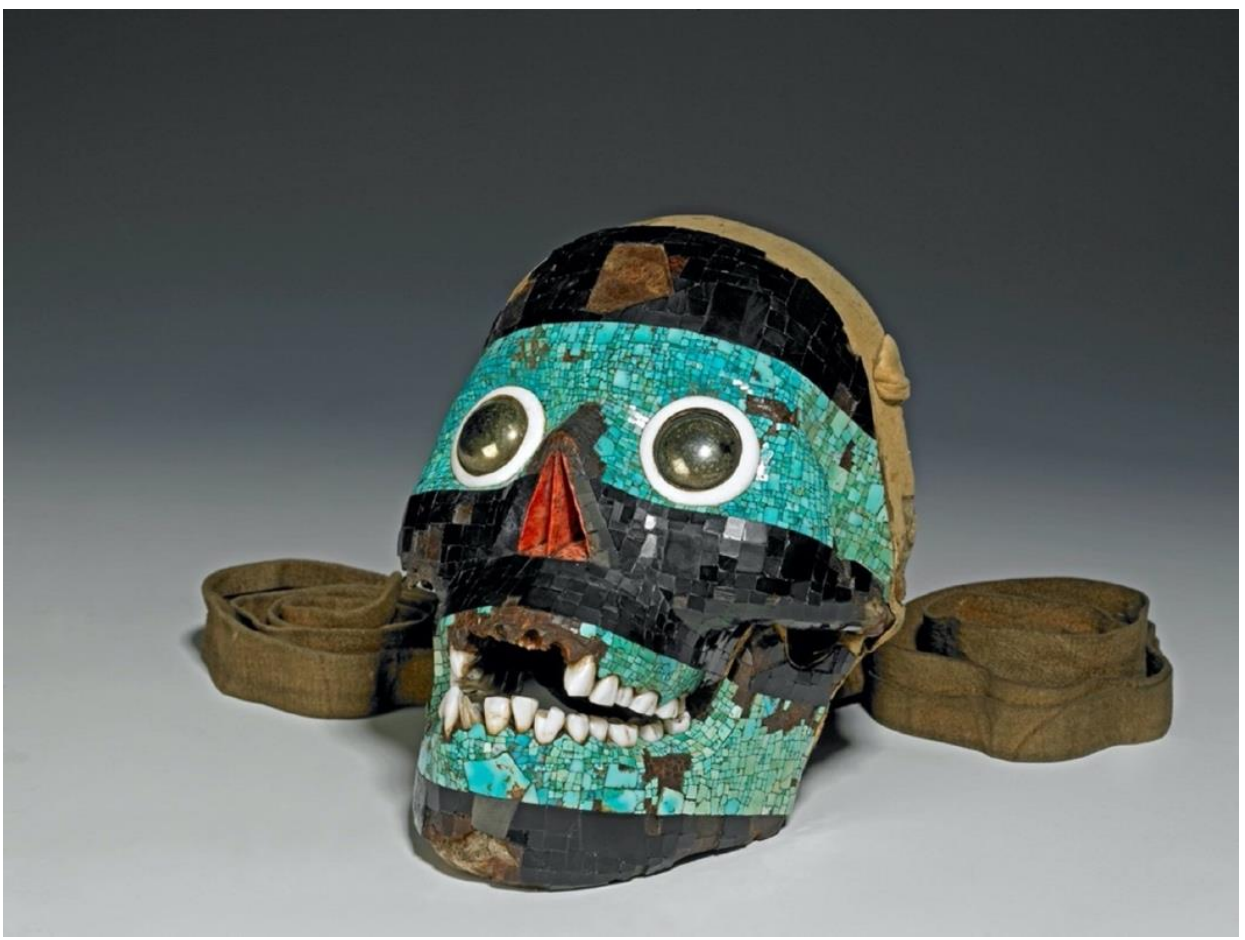

Figure 6. Mosaic skull mask of Tezcatlipoca (@ The Trustees of the British Museum). 
Milbrath (2014) observes that, for the Classic Maya, an equivalent for Tezcatlipoca may have been the deity known as K'awiil who also is associated with smoking mirrors and has a serpent replacing one foot (Figure 7a). K'awiil figures were commonly held by Classic Maya rulers, leading scholars to equate this figure with political accession and royal lineages (Rice 2012; Schele and Freidel 1990, pp. 294-301). For instance, on Stela 11 from Yaxchilan the masked Chaak impersonator holds a K'awiil manikan scepter (see Figure 3). Maya rulers impersonating the Jaguar God of the Underworld (JGU) also are shown holding K'awiil figures. For example, Stela 8 from Seibal shows the head of K'awiil being held by a ruler impersonating JGU (Figure 8). Like Tezcatlipoca, JGU appears associated with smoke, darkness, death, jaguar transformation, and sorcery (Figure $7 \mathrm{~b}$ ). Jaguars throughout Mesoamerica are connected to a range of "agonistic activities such as hunting, warfare, and sacrifice and [served] as the spirit familiar par excellence of shamans, priests, and political leaders" (Saunders and Baquedano 2014, p. 3). K'awiil is not as strongly associated with jaguars, but more closely connected to precious life-giving substances and fluids, such as maize and blood (Freidel et al. 1993, pp. 194-95). Stuart (1987) interprets the name K'awiil as "sustenance," which nourishes both human and other-than-human beings in a form of mutual care and obligation (Freidel et al. 1993, pp. 194-95). Notably, maize seeds, smoke, fire, and other shiny things—all embodiments of K'awiil—are consulted today by Mesoamerican shamans for answerability and likely were also used in the past for prognostication. In grasping the K'awiil sceptor and wearing the costuming of deathrelated gods like JGU and Chaak, we suggest Maya rulers acted as shamans, communing with powerful animate forces of life and death as a distinct means of knowing the world and acquiring knowledge.

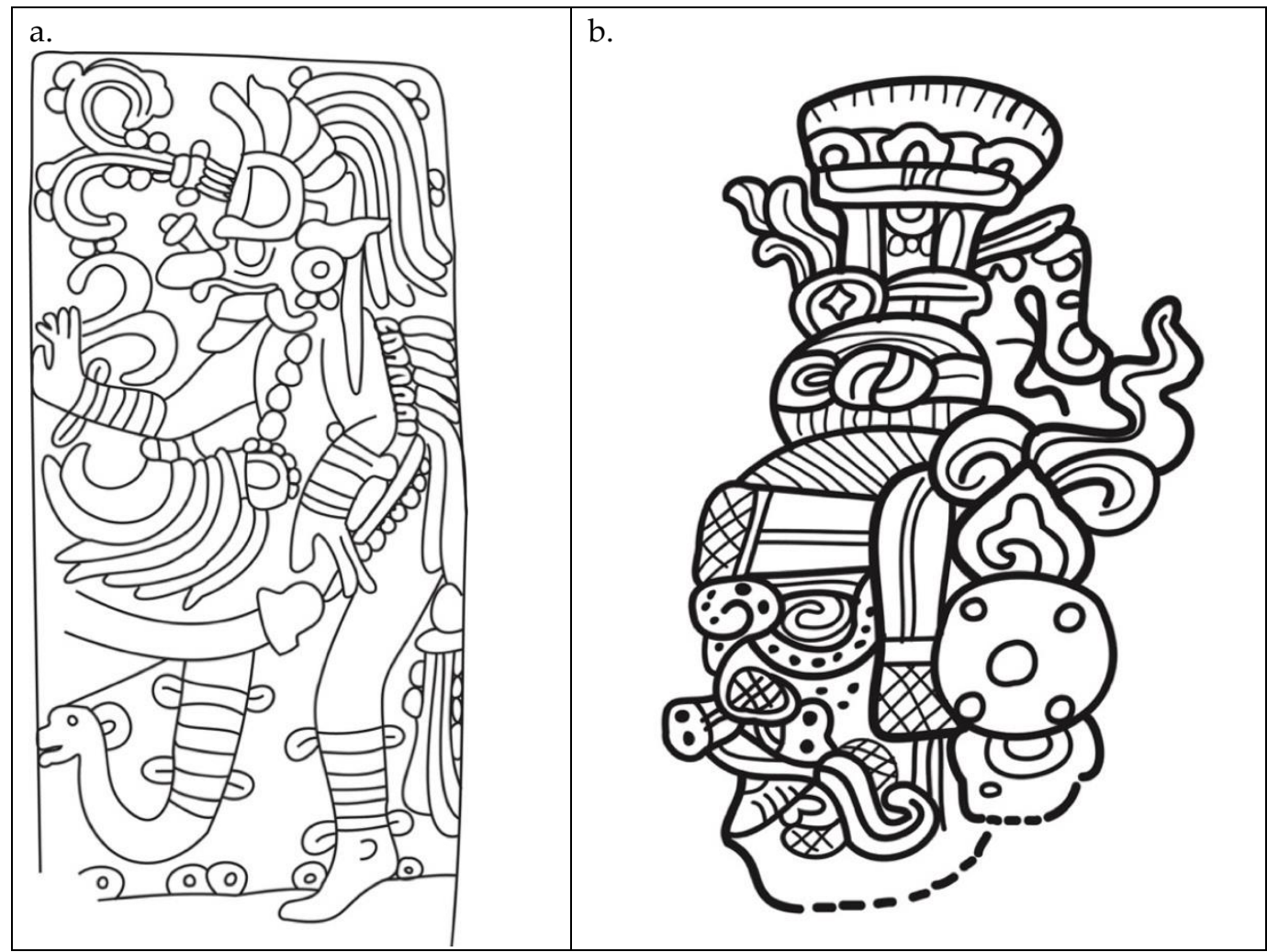

Figure 7. (a) Classic period relief of K'awiil from Maya site of Sayil showing both the serpent leg and smoking mirror similar to Tezcatlipoca (after Milbrath 2014: Figure 6. 3 h, redrawn by K. Titus); (b) Detail of Stela 31 from Maya site of Tikal showing JGU with facial "cruller" and smoking jaguar ear (courtesy of the Linda Schele Drawings Collection, (c) 2000 David Schele). 


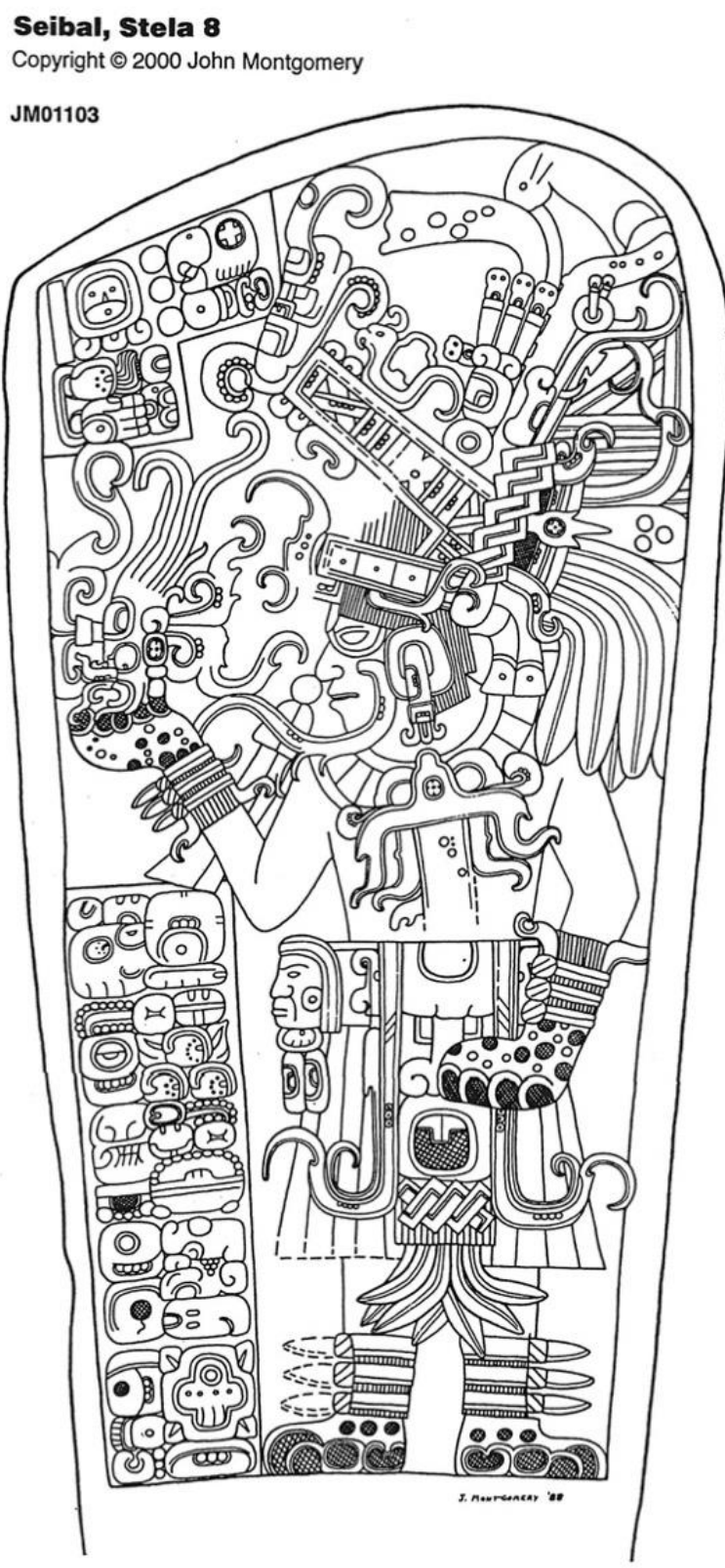

Figure 8. Stela 8 from Seibal (ㄷ 2000 John Montgomery).

\section{Ontological Relationships with the More-than-Human}

While most scholars agree that humans did not permanently assume power on a par with divinities (Houston and Stuart 1996; Martin 2020, pp. 144-48), human and divine beings both were capable of assuming a "preternatural quality in Mesoamerica, namely the ability to undergo a transformation into animals or natural phenomena at their own will" (Pharo 2007, p. 61). The presence of shape-shifting co-essences have been identified by the wahy glyph in Classic Maya epigraphic contexts, perhaps best understood as a "supernatural being with whom a person shares his or her consciousness" (Houston and Stuart 1989, p. 1; see also Grube and Nahm 1994). Stuart (2021, p. 184) in his most recent programmatic inquiry into the wahy category of being for the Classic Maya notes the cloudy relationship between these frighteningly demonic creatures and other kinds of supernatural beings often categorized as gods $\left(k^{\prime} u h\right)$ or "sacred entities" (Houston and Stuart 1989, p. 291). While the ontological relationships between such spirits and deities and their human counterparts remain complex and open to inquiry, it is clear that Maya royalty and elite engaged in conversive, co-creative bodily and spiritual engagement with 
the more-than-human realm by "conjuring" (tzak) and "birthing" such supernaturals into existence and into action (see Taube 1994 for several examples). Stuart (2021, p. 201) further suggests that the dark sorcerous qualities of wahy spirits were dangerous and afflictive and illuminate the power of Maya rulers to cast curses, affliction, and death upon enemies (see also Classic depictions in Grube and Nahm 1994).

As terrifying as these wahy spirits could be (Nielsen 2021), they could also be beneficent and might be best understood not merely as an evil spirit, but as an expression of ongoing disequilibrium in the world. In a relational ontology, the balance of power and control is never absolute, preordained, or guaranteed (Harrison-Buck 2020, pp. 435-36: for a contemporary Maya example see Vogt 1976, pp. 95-96). The ongoing tension that exists in the world may be expressed in one of the most common phrases found in Classic Maya hieroglyphic texts—ch'ahb ak'baal (Stuart 2005, p. 278). Central to Classic Maya rulership, this diaphrastic kenning is often glossed as "genesis and darkness." Stuart (2021, pp. 200-1) suggests this ancient couplet may allude to a "complex notion of power" that juxtaposes the positive and creative against the esoteric and nocturnal where the former embodies (re)generative power and the latter is an ontological status associated with death that is both dark and afflictive. The powers of shamans, generally, are both admired and feared because their use is always a matter of intention on the part of the human being in the ontological relationship, often overseeing aspects of procreation, birth, sickness and death. Successfully overcoming affliction, and death itself, is a common prerequisite to shamanic training and practice in Mesoamerica and rulers performed rituals of resurrection from Preclassic times onward (Freidel and Suhler 1999).

Shamans engaging with wahy spirits in ontological relation, with both living and deceased rulers, held the power to shift the equilibrium, either positively or negatively. The ambiguity and relational aspects of their power are cogently summarized by Oswaldo Chinchilla in his study of centipede spirits, including wahy spirits, and their conjuring by royal women who also appear to have wielded shamanic power, particularly in magical acts of birthing and midwifery. The imagery shows "... women as capable of controlling those creatures and summoning them to deliver children through their hideous maws. As conduits for the portentous birth of royal offspring, those beings seem to embody the genital organs of these powerful women, who are shown capable of magical control over the agents of sickness and death" (Chinchilla 2021, p. 228). Additional support for this form of shamanic impersonation is also found at El Peru-Waka, where Queen K'abel is depicted on the back of her mirror in Burial 61, shown conjuring a giant centipede and, in the tomb, she is shown birthing the death god Akan from her loins as a cave stone effigy (Navarro-Farr et al. 2021, Figure 6c; Navarro-Farr et al. n.d.). Through such intimate relations with the more-than-human, Maya kings and queens may have sought a moral balance between such forces and conditions in the cosmos (see Stuart 2021, p. 200). It may be that they were charged with managing the ongoing disequilibrium through their shamanic engagement and impersonation of supernatural powers where moral judgment would have had to be levied in light of the choices made and outcomes, good and bad, achieved through these interpersonal relations (Freidel et al. 1993, p. 224; Freidel and Shaw 2000; Golden and Scherer 2013).

\section{Seeing and Knowing with Mirrors and Other "Communicating Objects"}

Houston and Taube (2000, p. 287) note: "It is probably relevant that, in most Mayan languages, to see something is also to discern and understand; thus, the act of perception is regarded as physiological, but equally cognitive, intellectual, and, in the case of shamans, at once visionary and spiritually omniscient." Across Mesoamerica, there are creation stories featuring a male-female pair, sometimes referred to as the first 'mother-father' or original grandparents, who were "all-seeing" and "all-knowing" and are characterized as the first shamans, priests, and sorcerers who had the ability to foresee events in the future through divination. As the first diviners, this creator couple was also responsible for the creation of the world and of humans. The progenerative aspects of the 'mother-father' 
creator couple are expressed in the Quiché Maya Popol Vuh creation story, where they are described as creating the first four humans who "have perfect vision and therefore perfect knowledge" (Tedlock 1985, p. 47). Ultimately, they decide that humans should not have the same all-seeing and all-knowing power as the divine; they "put a fog in their eyes" (Tedlock 1985, p. 47) and "[humans] were blinded like breath upon the face of a mirror" (Christensen 2000, p. 134).

Houston et al. (2006, pp. 167-70) describe the sight of the gods as an agentive, "emanating eye" with their pupils rendered either with a distinctive spiral or a mirror glyphic element, which may distinguish visionary spirits of the night and of the day, respectively. For instance, the night sun aspect of Itzamnaaj, the so-called Jaguar God of the Underworld (JGU) described above, has spiral elements marking the eyes and is associated with jaguar features (Taube 1992, Figure 9a). Olmec figurines sometimes have inset iron pyrite mirror eyes and Early Classic figurines at Teotihuacan also sometimes feature pyrite mirror eyes. The goddess figurine found in Burial 2 of the Moon Pyramid at Teotihuacan is one such example (Robb 2017, plate 99). A similar pattern is found later in the Postclassic where depictions, like the Aztec Tezcatlipoca skull mask described above, also feature mirror eyes made of polished pyrite (see Figure 6).

Across Mesoamerica, the jaguar and particularly the jaguar's eyes are identified with mirrors (Blainey 2016, pp. 181-282; Saunders 1988, pp. 9-12). Saunders (1988, 2001) has observed the connection between the jaguar's eyes and their mirrorlike reflections at night and has illustrated the close associations between jaguars, mirrors and Tezcatlipoca, the Aztec god of darkness, death, and sorcery described above. Jaguar elements are also commonly associated with the Postclassic Yucatec creator Itzamnaaj and his female counterpart Ix Chel (Tedlock 2010, p. 162). In addition to jaguar features, their divining seeds, acts of bloodletting, and their use of the 260-day ritual almanac exemplifies the all-knowing aspects of the creator pair across Mesoamerica. Their 'all-seeing' knowledge is also expressed by the rendering of their eyes, shown as shiny objects, usually interpreted as mirrors (Taube 1992, pp. 181-82). In Classic Mayan hieroglyphic texts, the "mirror" glyph, also more generally designating hard, reflective or shiny materials, such as polished jade celts (Taube 2005; Stuart 2005), is used to render the pupils of Itzamnaaj and other all-seeing powerful spirits (see Houston et al. 2006, p. 170, Figure 4.27).

When found in the archaeological record, mirrors often are interpreted as tools for divinatory "scrying" (Healy and Blainey 2011). Mirrors are found across ancient Mesoamerica, most often in burial and cache deposits, beginning as early as the Middle Preclassic period and continuing through the Classic and Postclassic (Blainey 2007). Where preserved, the reflective side of ground surface mirrors are made of iron ore, magnetite, ilmenite, hematite or sometimes obsidian; most often, however, mirrors were made with pyrite cut and polished into tesserae and assembled to create a mosaic pattern with a flat reflective surface glued onto a backing. For example, a plaster-backed pyrite mirror was found in a Late Terminal Preclassic (A.D. 100-250) burial from the site of Yogüe in the lower Rio Valley of Oaxaca, which was associated with a young male and worn as a pectoral (Barber and Sánchez 2012; Brzezinski et al. 2017). The average diameter of mirrors measures roughly $15 \mathrm{~cm}$ and they are typically made with a carved slate backing with two to four drill holes, presumably so they could be worn. While the majority of pyrite mosaic mirrors have been found in Maya archaeological contexts, they have a widespread distribution (Gallaga 2014). It is clear that mirrors were central to ritual practice in the ancient city of Teotihuacan in Central Mexico (e.g., Sugiyama et al. 2013). Over two hundred slate backings representing such mirrors as protective military devices were discovered with sacrifices in the Feathered Serpent Temple at Teotihuacan (Sugiyama 1992) and many more have been discovered in other investigations of this ancient city (see also Robb 2017; Taube 1992).

Houston et al. (2006, pp. 167-71) conclude that the reflective brilliance of mirrors was equated with seeing in the form of a penetrating all-knowing agentive power linked with the eyes of personified supernatural essences who often were the focus of impersonation. According to these scholars, impersonators "share in the divinity of gods" and are what 
they refer to as "the practice of 'concurrence,' of essences that can inhabit the same space at the same time" (Houston et al. 2006, p. 66). Impersonators and, by extension, their mirrors, masks and other costuming stand as representations of the deified co-essences; but are more than mere symbolic intermediaries or dramatological reenactments of a divine spirit. Taube $(1992,2016)$, in his extensive reviews of mirror-use in ancient Mesoamerica, notes that they were portals from which supernatural beings could emerge. These reflective objects may be best understood as "communicating objects" (Astor-Aguilera 2010) or what Taube (2016, p. 302) refers to as the "speaking mirror." We suggest that mirrors as well as masks, headdresses, and other costuming - whether worn by a human or disembodiedfunctioned as active participants in acts of divination (see also Houston et al. (2006, p. 273) for an example from Palenque where a disembodied headdress engages with a ruler and members of the court). These "communicating objects" were not just a possessed object or tool; they engaged in intimate, intersubjective relationships between object and spirit, person and soul (Astor-Aguilera 2010) and actively engaged with the impersonator seeking "answerability" (sensu Molesky-Poz 2006).

\section{Conclusions}

In this study, we consider both the productive and afflictive engagements with the spirit world in ancient Mesoamerica, which wielded significant political power from Preclassic times onward. For instance, depending on the context, ancient Maya rulers impersonated Itzamnaaj, the sun-filled Kinich Ahau or his night sun counterpart, the socalled Jaguar God of the Underworld, or communed with various wahy spirits-all of whom had the power to potentially shift the equilibrium, positively or negatively. It is difficult to imagine how a relational perspective can be successfully employed in political understandings of ancient Mesoamerica if we only engage in shamanism as a "primitive" religious structure and consider animism as merely a projection of imagination onto things (sensu Ingold 2006, p. 10; see also Harvey 2006). To more effectively address alternative ontologies of power we suggest looking outside the normative structures of "Western" politics, where often power is "viewed only in the negative-equated with inequality, disenfranchisement, resistance, etc." (Morehart et al. 2018, p. 12). Ethnographic studies across Mesoamerica describe other means of power in the form of spirit communication and affliction, targeted evil doings ("witchcraft" or "sorcery"), vulnerability and protection from evil winds, curing rituals to restore the souls of human and other-than-human beings, and a range of other practices that anthropologists describe in terms of a shamanic-animistic ontology (Knab 2004, pp. 153-54; Redfield and Villa Rojas [1934] 1964, pp. 177-80; Vogt 1976, pp. 61-96; Watanabe 1992, pp. 190-94, 208-10).

Shamans in ancient Mesoamerica held leadership positions because they had to contend with the serious and delicate matter of managing this disequilibrium, which was a central concern of power and politics and constituted an ongoing ontological struggle in-the-world. It is the tension between the spiritual and the material, or what Mesoamerican peoples refer to as the 'Heart of Heaven and Heart of Earth' that must be carefully managed by trained specialists (Hart 2008; Tedlock 1982; Vogt 1966, 1976). Importantly, answerability for contemporary shamans is formed through an embodied cognition, which involves both materialism - such as medicinal plants and other physical remedies-and spiritualism in the form of prayer and magical spirit communication (Hart 2008, pp. 11920). In this way, shamanism in Mesoamerica is best described as "conversively co-creative" (sensu Brill de Ramírez 2007), relying on both discursive (cognitive) and non-discursive (bodily) experience as ways of knowing the world and acquiring knowledge (see also Harrison-Buck and Hendon 2018). Considering a relational ontology of shamanism and animism from a conversive perspective, we are more inclined to approach both the physical and mental properties of matter and thought as symmetrical and mutually dependent constitutive relations, considering the continuum of relational fields where both humans and nonhumans are potentially animate agents. 
Like any comparative anthropological terms, concepts like shamanism and animism are only deeply informative when explicitly defined using specific case studies and when grounded in terms of the local language. In the case of Mesoamerica, we are fortunate to have a rich ethnographic, archaeological, and epigraphic record that helps us to establish the ways in which these groups are ontologically different and to avoid homogenizing Indigenous practices over time and space (Astor-Aguilera 2010, pp. 14-15). In our attempt to "refigure" shamanism and animism beyond the confines of a "primitive" religious structure, we follow in the path of others who have emphasized a plurality of epistemologies (Bird-David 1999, p. 68; see also Bird-David 2017) and ontological multiplicity (Blaser 2013, p. 552). In this way, we recast these traditional anthropological constructs in terms of a relational performance or enactment grounded in Indigenous thought, as opposed to a foundational claim or essentialist fact about how the world operates.

As Todd (2016) observes, to rely solely on Euro-Western thought to explore ontological difference in Americanist archaeology is to perpetuate a colonial legacy which historically marginalizes or discredits Indigenous thought. Taking Indigenous ontological commitments seriously means applying their philosophies as analytical framework, not just as archaeological evidence (sensu Montgomery 2021, pp. 54-55). To move shamanism and animism out of their long-standing "savage slot" in anthropology, we consider these comparative terms not as static religious structures, but as ongoing relations with the environment that Indigenous peoples describe as distinct ways of knowing and acquiring knowledge about the world in which they live. Rather than merely passive agents or inert objects, we consider spirit impersonation and objects like mirrors as "communicating objects" (sensu Astor-Aguilera 2010). These more-than-human entities were active participants involved in two-way divinatory relations with the impersonator. As relational beings, both humans and objects, such as masks and mirrors, served as receptacles for personified co-essences where they were able to temporarily engage in a shared consciousness to achieve answerability and to manage the ongoing disequilibrium in-the-world.

Author Contributions: Conceptualization, E.H.-B. and D.A.F.; investigation, E.H.-B. and D.A.F.; writing-original draft preparation, E.H.-B.; writing-review and editing, E.H.-B. and D.A.F.; visualization, E.H.-B. and D.A.F. All authors have read and agreed to the published version of the manuscript.

Funding: This research received no external funding.

Conflicts of Interest: The authors declare no conflict of interest.

\section{References}

Abadia, Oscar Moro, and Martin Porr, eds. 2021. Ontologies of Rock Art: Images, Relational Approaches and Indigenous Knowledge. New York: Routledge.

Alberti, Benjamin. 2016. Archaeologies of Ontology. Annual Review of Anthropology 45: 163-79. [CrossRef]

Alberti, Benjamin, and Tamara L. Bray, eds. 2009. Animating Archaeology: Of Subjects, Objects and Alternative Ontologies. Special Section, Cambridge Archaeological Journal 19: 337-43.

Alberti, Benjamin, and Yvonne Marshall. 2009. Animating Archaeology: Local Theories and Conceptually Open-ended Methodologies. Cambridge Archaeological Journal 19: 344-56. [CrossRef]

Astor-Aguilera, Miguel A. 2010. The Maya World of Communicating Objects: Quadripartite Crosses, Trees, and Stones. Albuquerque: University of New Mexico Press.

Atalay, Sonya. 2006. Indigenous Archaeology as Decolonizing Practice. American Indian Quarterly 30: 280-310. [CrossRef]

Atalay, Sonya. 2008. Multivocality and Indigenous Archaeologies. In Evaluating Multiple Narratives: Beyond Nationalist, Colonialist, Imperialist Archaeologies. Edited by Junko Habu, Clare Fawcett and John M. Matsunaga. New York: Springer, pp. 29-44.

Atalay, Sonya. 2012. Community-Based Archaeology Research with, by, and for Indigenous and Local Communities. Berkeley: University of California Press.

Atalay, Sonya. 2020. Indigenous Science for a World in Crisis. Public Archaeology, 1-16. [CrossRef]

Atkinson, Jeanne M. 1992. Shamanisms Today. Annual Review of Anthropology 21: 307-30. [CrossRef]

Barber, Sarah B., and Mireya Olvera Sánchez. 2012. A Divine Wind: The Arts of Death and Music in Terminal Formative Oaxaca. Ancient Mesoamerica 23: 9-24. [CrossRef]

Barrera Vasquez, Alfredo. 1980. Diccionario Maya Cordemex, Maya-Español, Español-Maya. Merida: Ediciones Cordemex. 
Beekman, Christopher M. 2020. Unseating the Shaman: Narrative Performances and Co-Essences and the Hallow Figures in West Mexico. In Anthropomorphic Imagery in the Mesoamerican Highlands: Gods, Ancestors, and Human Beings. Edited by Brigitte Faugère and Christopher M. Beekman. Boulder: University of Colorado Press, pp. 68-107.

Bennett, Jane. 2010. Vibrant Matter: A Political Ecology of Things. Durham: Duke University Press.

Bird-David, Nurit. 1999. "Animism" Revisited: Personhood, Environment, and Relational Epistemology. Current Anthropology 40: S67-S91. [CrossRef]

Bird-David, Nurit. 2017. Us, Relatives, Scaling the Plural Life in a Forager World. Berkeley: University of California Press.

Blainey, Marc G. 2007. Surfaces and Beyond: The Political, Ideological, and Economic Significance of Ancient Maya Iron-Ore Mirrors. Master's thesis, Department of Anthropology, Trent University, Peterborough, ON, Canada.

Blainey, Marc G. 2016. Techniques of Luminosity: Iron-Ore Mirrors and Entheogenic Shamanism among the Ancient Maya. In Manufactured Light: Mirrors in the Mesoamerican Realm. Edited by Emiliano Gallaga M. and Marc G. Blainey. Boulder: University Press of Colorado, pp. 179-206.

Blaser, Mario. 2013. Ontological Conflicts and the Stories of Peoples in Spite of Europe: Toward a Conversation on Political Ontology. Current Anthropology 54: 547-68. [CrossRef]

Boyd, Carolyn E. 1996. Shamanic Journeys into the Otherworld of the Archaic Chichimec. Latin American Antiquity 7: 152-64. [CrossRef]

Brzezinski, Jeffrey, Arthur A. Joyce, and Sarah B. Barber. 2017. Constituting Animacy and Community in a Terminal Formative Bundled Offering from the Coast of Oaxaca, Mexico. Cambridge Archaeological Journal 27: 511-31. [CrossRef]

Brill de Ramírez, Susan Berry. 2007. Native American Life-history Narratives: Colonial and Postcolonial Navajo Ethnography. Albuquerque: University of New Mexico Press.

Brown, Linda A., and Kitty F. Emery. 2008. Negotiations with the Animate Forest: Hunting Shrines in the Guatemalan Highlands. Journal of Archaeological Method and Theory 15: 300-37. [CrossRef]

Brown, Linda A., and William H. Walker, eds. 2008. Prologue: Archaeology, Animism and Nonhuman Agents. Journal of Archaeological Method and Theory 15: 297-99. [CrossRef]

Castrén, Matthias Alexander. 1853. Vorlesungen uber die finnische Mythologie. Nordische Reisen und Forschungen vol. 3. St. Petersburg: Kaiserlichen Akademie der Wissenschaften.

Chinchilla, Oswaldo Mazariegos. 2021. Where Children are Born: Centipedes and Feminine Sexuality in Ancient Mesoamerica. In Sorcery in Mesoamerica. Edited by Jeremy D. Coltman and John M. D. Pohl. Boulder: University of Colorado Press, pp. $206-35$.

Christensen, Allen J. 2000. Popol Vuh: The Mythic Sections, Tales of First Beginnings from the Ancient K'iche'-Maya. Provo: Foundation for Ancient Research and Mormon Studies at Brigham Young University.

Coe, Michael. 1995. The Olmec World: Ritual and Rulership. Princeton: Princeton University Art Museum.

Coltman, Jeremy D., Guilhem Olivier, and Gerard van Bussel. 2020. An Effigy of Tezcatlipoca from the Bilimek Collection in Vienna. Ancient Mesoamerica 31: 343-59. [CrossRef]

Durkheim, Emile. 1961. The Elementary Forms of the Religious Life. Translated by Joseph Ward Swain. New York: Collier Books. First published 1912.

Eliade, Mircea. 1964. Shamanism: Archaic Techniques of Ecstasy. Princeton: Princeton University Press.

Erazo, Juliet, and Christopher Jarrett. 2017. Managing Alterity from Within: The Ontological Turn in Anthropology and Indigenous Efforts to Shape Shamanism. Journal of the Royal Anthropological Institute (N.S.) 24: 145-63. [CrossRef]

Fowles, Severin M. 2013. An Archaeology of Doings: Secularism and the Study of Pueblo Religion. Santa Fe: SAR.

Freidel, David A., Linda Schele, and Joy Parker. 1993. Maya Cosmos: Three Thousand Years on the Shaman's Path. New York: Harper Collins.

Freidel, David, and Justine Shaw. 2000. The Lowland Maya Civilization, Historical Consciousness and Environment. In The Way the Wind Blows: Climate, History, and Human Action. Edited by Roderick S. MacIntosh, Joseph A. Tainter and Susan K. MacIntosh. New York: Columbia University Press, pp. 271-300.

Freidel, David A., and Charles K. Suhler. 1999. The Path of Life: Towards a Functional Analysis of Ancient Maya Architecture. In Mesoamerican Architecture as a Cultural Symbol. Edited by Jeff Karl Kowalski. Oxford: Oxford University Press, pp. $250-75$.

Furst, Peter. 1965. West Mexican Tomb Sculpture as Evidence for Shamanism in Prehispanic Mesoamerica. Antropologica 15: $29-60$.

Furst, Peter. 1968. The Olmec Were-Jaguar Motif in the Light of Ethnographic Reality. In Dumbarton Oaks Conference on the Olmec. Edited by Elizabeth P. Benson. Washington, DC: Dumbarton Oaks, pp. 143-78.

Furst, Peter. 1976. Shamanistic survivals in Mesoamerican Religion. In Actas, XLI Congreso Internacional de Americanistas, Mexico, 2 al 7 de septiembre de 1974. Mexico City: Comisión de Publicación de las Actas y Memorias, vol. 2, pp. 151-57.

Furst, Peter. 1994. Ancient Traditions: Shamanism in Central Asia and the Americas. Museum of Natural History. Boulder: University Press of Colorado.

Furst, Jill Leslie. 1997. The Natural History of the Soul in Ancient Mexico. New Haven: Yale University Press.

Gallaga, Emiliano. 2014. Pyrite-Encrusted Mirrors at Snaketown and their External Relationships to Mesoamerica. KIVA: The Journal of Southwestern Anthropology and History 79: 280-99. [CrossRef]

Gheorghiu, Dragos,, Gheorghiu, Emilia Pásztor, Herman Bender, and George Nash, eds. 2017. Archaeological Approaches to Shamanism: Mind-Body, Nature, and Culture. Tyne: Cambridge Scholars Publishing.

Golden, Charles, and Andrew Scherer. 2013. Territory, Trust, Growth, and Collapse in Classic Period Maya Kingdoms. Current Anthropology 54: 397-435. [CrossRef] 
Grove, David C. 1970. The Olmec Paintings of Oxtotitlan Cave, Guerrero, Mexico. Dumbarton Oaks Studies in Pre-Columbian Art and Archeology. Washington, DC: Dumbarton Oaks Research Library and Collection.

Grube, Nikolai, and Werner Nahm. 1994. A Census of Xibalba: A Complete Inventory of Way Characters on Maya Ceramics. In The Maya Vase Book: A Corpus of Rollout Photographs of Maya Vases. Edited by Justin Kerr. vols. 4. New York: Kerr Associates, pp. 686-715.

Halperin, Christina T. 2018. How Animistic Entities Make History: Maya Materialities and Spiritualities Over the Longue Durée. In Relational Engagements of the Indigenous Americas: Alterity, Ontology, and Shifting Paradigms. Edited by Melissa R. Baltus and Sarah E. Baires. Landham: Lexington Books, pp. 87-107.

Hart, Thomas. 2008. The Ancient Spirituality of the Modern Maya. Albuquerque: University of New Mexico Press.

Harris, Oliver J. T. 2021a. What Do We Mean By Relational Anyway? In Archaeological Theory in Dialogue: Situating Relationality, Ontology, Posthumanism, and Indigenous Paradigms. Written by Rachel J. Crellin, Craig N. Cipolla, Lindsay M. Montgomery, Oliver J. T. Harris, and Sophie V. Moore. New York: Routledge Press, pp. 15-34.

Harris, Oliver J. T. 2021b. Discussing Indigenous Difference: Translation, Ontology, and the Future of European Prehistory. In Archaeological Theory in Dialogue: Situating Relationality, Ontology, Posthumanism, and Indigenous Paradigms. Written by Rachel J. Crellin, Craig N. Cipolla, Lindsay M. Montgomery, Oliver J. T. Harris, and Sophie V. Moore. New York: Routledge Press, pp. 69-84.

Harrison-Buck, Eleanor. 2012a. Architecture as Animate Landscape: Circular Structures in the Ancient Maya Lowlands. American Anthropologist 114: 64-80. [CrossRef]

Harrison-Buck, Eleanor. 2012b. Rituals of Death and Disempowerment Among the Maya. In Power and Identity in Archaeological Theory and Practice: Case Studies from Ancient Mesoamerica. Edited by E. Harrison-Buck. Foundations of Archaeological Inquiry. Salt Lake City: University of Utah Press, pp. 103-15.

Harrison-Buck, Eleanor. 2015. Maya Religion and Gods: Relevance and Relatedness in the Animic Cosmos. In Tracing the Relational: The Archaeology of Worlds, Spirits, and Temporalities. Edited by Meghan E. Buchanan and B. Jacob Skousen. Foundations of Archaeological Inquiry. Salt Lake City: University of Utah Press, pp. 115-29.

Harrison-Buck, Eleanor. 2018. Relational Matters of Being: Personhood and Agency in Archaeology. In Relational Identities and Other-than-Human Agency in Archaeology. Edited by Eleanor Harrison-Buck and Julia A. Hendon. Louisville: University Press of Colorado, pp. 263-82.

Harrison-Buck, Eleanor. 2020. Maya Relations with the Material World. In The Maya World. Edited by Scott Hutson and Traci Ardren. New York: Routledge, pp. 424-42.

Harrison-Buck, Eleanor, and Julia A. Hendon. 2018. An Introduction to Relational Personhood and Other-than-Human Agency in Archaeology. In Relational Identities and Other-than-Human Agency in Archaeology. Edited by Eleanor Harrison-Buck and Julia A. Hendon. Louisville: University Press of Colorado, pp. 3-28.

Harrison-Buck, Eleanor, Astrid Runggaldier, and Alex Gantos. 2018. It's the Journey not the Destination: Maya New Year's Pilgrimage and Self-Sacrifice as Regenerative Power. Journal of Social Archaeology 18: 325-47. [CrossRef]

Harvey, Graham. 2006. Animals, Animists, and Academics. Zygon 41: 9-20. [CrossRef]

Hayden, Brian. 2003. Shamans, Sorcerers, and Saints: Prehistory of Religion. Washington, DC: Smithsonian Books.

Healy, Paul F., and Marc G. Blainey. 2011. Ancient Maya Mosaic Mirrors: Function, Symbolism, and Meaning. Ancient Mesoamerica 22: 229-44. [CrossRef]

Hendon, Julia A. 2010. Houses in a Landscape: Memory and Everyday Life in Mesoamerica. Durham: Duke University Press.

Hendon, Julia A. 2012. Objects as Persons: Integrating Maya Beliefs and Anthropological Theory. In Power and Identity in Archaeological Theory and Practice: Case Studies from Ancient Mesoamerica. Edited by E. Harrison-Buck. Foundations of Archaeological Inquiry. Salt Lake City: University of Utah Press, pp. 82-89.

Hendon, Julia A. 2018. Can Tools Have Souls? Maya Views on the Relations between Human and Other-than-Human Persons. In Relational Identities and Other-than-Human Agency in Archaeology. Edited by Eleanor Harrison-Buck and Julia A. Hendon. Louisville: University Press of Colorado, pp. 147-66.

Houston, Stephen D. 2014. The Life Within: Classic Maya and the Matter of Permanence. New Haven: Yale University Press.

Houston, Stephen D., and David Stuart. 1989. The Way Glyph: Evidence for "Co-Essences" among the Classic Maya. Research Reports on Ancient Maya Writing series, no. 30. Barnardsville: Center for Maya Research.

Houston, Stephen D., and David Stuart. 1996. Of Gods, Glyphs, and Kings: Divinity and Rulership among the Classic Maya. Antiquity 70: 289-312. [CrossRef]

Houston, Stephen D., and Karl A. Taube. 2000. An Archaeology of the Senses: Perception and Cultural Expression in Ancient Mesoamerica. Cambridge Archaeological Journal 10: 261-94. [CrossRef]

Houston, Stephen D., David Stuart, and Karl Taube. 2006. The Memory of Bones: Body, Being, and Experience among the Classic Maya. Austin: University of Texas Press.

Ingold, Timothy. 2006. Rethinking the Animate, Re-Animating Thought. Ethnos 71: 9-20. [CrossRef]

Jackson, Sarah. 2017. Envisioning Artifacts: A Classic Maya View of the Archaeological Record. Journal of Archaeological Method and Theory 24: 579-610. [CrossRef]

Jackson, Sarah. 2019. Facing Objects: An Investigation of Non-Human Personhood in Classic Maya Contexts. Ancient Mesoamerica 30: 31-44. [CrossRef] 
Joyce, Arthur A., and Sarah B. Barber. 2015. Ensoulment, Entrapment, and Political Centralization: A Comparative Study of Religion and Politics in Later Formative Oaxaca. Current Anthropology 56: 819-47. [CrossRef]

Kappelman, Julia Guernsey. 2001. Sacred Geography at Izapa and the Performance of Rulership. In Space, Power, and Poetics in Ancient Mesoamerica. Edited by Rex Koontz, Kathryn Reese-Taylor and Annabeth Headrick. Boulder: Westview Press, pp. 81-111.

Kappelman, Julia Guernsey. 2004. Demystifying the Late Preclassic Izapan-Style Stela-Altar "Cult". RES: Anthropology and Aesthetics 45: 99-122. [CrossRef]

Klein, Cecelia F. 1986. Masking Empire: The Material Effects of Masks in Aztec Mexico. Art History 9: 135-67. [CrossRef]

Klein, Cecelia F., Eulogio Guzmán, Elisa C. Mandell, and Maya Stanfield-Mazzi. 2002. The Role of Shamanism in Mesoamerican Art: A Reassessment. Current Anthropology 43: 383-419. [CrossRef]

Knab, Timothy J. 2004. The Dialogue of Earth and Sky. Tucson: University of Arizona Press.

Kosiba, Steve. 2020. The Nature of the World, the Stuff of Politics: Exploring Animacy and Authority in the Indigenous Americas. In Sacred Matter: Animacy and Authority in the Americas. Edited by Steve Kosiba, John W. Janusek and Thomas B. F. Cummins. Washington, DC: Dumbarton Oaks Research Library and Collection, pp. 1-26.

Kosiba, Steve, John W. Janusek, and Thomas B. F. Cummins, eds. 2020. Sacred Matter: Animacy and Authority in the Americas. Washington, DC: Dumbarton Oaks Research Library and Collection.

Kovacevich, Brigitte. 2014. The Inalienability of Jades in Mesoamerica. Archaeological Papers of the American Anthropological Association 23: 95-111. [CrossRef]

Kovacevich, Brigitte. 2017. The Value of Labor: How the Production Process Added Value to Pre-Columbian Maya Jade. In The Value of Things: Prehistoric to Contemporary Commodities in the Maya Region. Edited by Jennifer Matthews and Thomas Guderjan. Tucson: University of Arizona Press, pp. 17-20.

Looper, Matthew. 2018. Objects with Voices among the Ancient Maya. In Relational Identities and Other-than-Human Agency in Archaeology. Edited by Eleanor Harrison-Buck and Julia A. Hendon. Louisville: University Press of Colorado, pp. 126-46.

Lopez Austin, Alfredo. 1988. Human Biology and Ideology: Concepts of the Ancient Nahuas. Translated by T. Ortiz de Montellano, and B. R. Ortiz de Montellano. 2 vols. Salt Lake City: University of Utah Press.

Love, Bruce. 2012. Maya Shamanism Today: Connecting with the Cosmos in Rural Yucatan. San Francisco: Precolumbia Mesoweb Press.

La Farge, Oliver. 1947. Santa Eulalia: The Religion of a Cuchumatán Indian Town. Chicago: University of Chicago Press.

La Farge, Oliver, and Douglas S. Byers. 1931. The Year Bearer's People. New Orleans: Department of Middle American Research, The Tulane University of Louisiana.

Laluk, Nicholas. 2017. The Indivisibility of Land and Mind: Indigenous Knowledge and Collaborative Archaeology within Apache Contexts. Journal of Social Archaeology 17: 92-112. [CrossRef]

Madsen, William. 1955. Shamanism in Mexico. Southwestern Journal of Anthropology 11: 48-57. [CrossRef]

Mallery, Garrick. 1893. Picture-Writing of the American Indians. In Tenth Annual Report of the Bureau of Ethnology to the Secretary of the Smithsonian Institution, 1888-1889. Washington, DC: Government Printing Office.

Markman, Roberta H., and Peter T. Markman. 1989. Masks of the Spirit: Image and Metaphor in Mesoamerica. Berkeley: University of California Press.

Martin, Simon. 2015. The Old Man of the Maya Universe: A Unitary Dimension to Ancient Maya Religion. In Maya Archaeology 3. Edited by Charles Golden, Stephen D. Houston and Joel Skidmore. San Francisco: Precolumbia Mesoweb Press, pp. $186-227$.

Martin, Simon. 2020. Ancient Maya Politics: A Political Anthropology of the Classic Period 150-900 CE. Cambridge: Cambridge University Press.

McEwan, Colin, Andrew Middleston, Caroline Cartwright, and Rebecca Stacy. 2006. Turquoise Mosaics from Mexico. Durham: Duke University Press.

Milbrath, Susan. 2014. The Maya Lord of the Smoking Mirror. In Tezcatlipoca: Trickster and Supreme Deity. Edited by Elizabeth Baquedano. Boulder: University Press of Colorado, pp. 163-96.

Molesky-Poz, Jean. 2006. Contemporary Maya Spirituality: The Ancient Ways are Not Lost. Austin: University of Texas Press.

Montgomery, Lindsay M. 2021. Indigenous Alterity as Archaeological Praxis. In Archaeological Theory in Dialogue: Situating Relationality, Ontology, Posthumanism, and Indigenous Paradigms. Written by Rachel J. Crellin, Craig N. Cipolla, Lindsay M. Montgomery, Oliver J.T. Harris and Sophie V. Moore. New York: Routledge Press, pp. 51-68.

Morehart, Christopher T., John K. Millhauser, and Santiago Juarez. 2018. Archaeologies of Political Ecology-Genealogies, Problems, and Orientations. Archaeological Papers of the American Anthropological Association 29: 5-29. [CrossRef]

Navarro-Farr, Olivia, Griselda Pérez Robles, Juan Carlos Pérez Calderón, Elsa Damaris Menéndez Bolaños, Erin E. Patterson, Keith Eppich, and Mary Kate Kelly. 2021. Burial 61 at El Peru-Waka's Structure M13-1. Latin American Antiquity 32: 188-200. [CrossRef]

Navarro-Farr, Olivia, Juan Carlos Perez, Griselda Perez, Michelle Rich, and David Freidel. n.d. Birthing Gods: Queen K'abel's Mirrors, Plates, Writing Tablets. In Recent Research on Iron Ore Mirrors in Mesoamerica and Central America. Special Section to be Submitted to Ancient Mesoamerica. Edited by Matthieu Ménager, Silvia Salgado and David Freidel. in prep.

Nielsen, Jesper. 2021. 'The Devil Incarnate': A Comparative Perspective on 'Deer-Serpents' in Mesoamerican Beliefs and Ritual Practices. In Sorcery in Mesoamerica. Edited by Jeremy D. Coltman and John M. D. Pohl. Boulder: University of Colorado Press, pp. 236-82.

Oakes, Maud. 1951. The Two Crosses of Todos Santos: Survivals of Mayan Religious Ritual. Bolligen Series, no. 27; Princeton: Princeton University Press. 
Olivier, Guilhem. 2014. Enemy Brothers or Divine Twins? A Comparative Approach between Tezcatlipoca and Quetzalcoatl, Two Major Deities from Ancient Mexico. In Tezcatlipoca: Trickster and Supreme Deity. Edited by Elizabeth Baquedano. Boulder: University Press of Colorado, pp. 59-82.

Porr, Martin, and Hannah R. Bell. 2012. 'Rock-art', 'Animism' and Two-way Thinking: Towards a Complementary Epistemology in the Understanding of Material Culture and 'Rock-art' of Hunting and Gathering People. Journal of Archaeological Method and Theory 19: 161-205. [CrossRef]

Pharo, Lars K. 2007. The Concept of "Religion" in Mesoamerican Languages. Numen 54: 28-70. [CrossRef]

Pharo, Lars K. 2011. A Methodology for a Deconstruction and Reconstruction of the Concepts "Shaman" and "Shamanism". Numen 58: 6-70. [CrossRef]

Redfield, Robert, and Alonso Villa Rojas. 1964. Chan Kom, A Maya Village. Chicago: University of Chicago Press. First published 1934.

Reilly, F. Kent, III. 1989. The Shaman in Transformation Pose: A Study of the Theme of Rulership in Olmec Art. Record of the Art Museum, Princeton University 48: 4-21. [CrossRef]

Reilly, F. Kent III. 1995. Art, Ritual, and Rulership in the Olmec World. In The Olmec World: Ritual and Rulership. Edited by Michael Coe. Princeton: Princeton University Art Museum, pp. 27-46.

Rice, Prudence. 2012. Continuities in Maya Political Rhetoric: K'awiils, K'atuns, and Kennings. Ancient Mesoamerica 23: 103-14. [CrossRef]

Robb, Mathew H., ed. 2017. Teotihuacan, City of Water, City of Fire. Berkeley: University of California Press.

Saunders, Nicholas J. 1988. Chatoyer: Anthropological Reflections on Archaeological Mirrors. In Recent Studies in Pre-Columbian Archaeology. Edited by Nicholas J. Saunders and Olivier de Montmollin. Oxford: BAR, International Series 421. pp. 1-37.

Saunders, Nicholas J. 1990. Tezcatlipoca: Jaguar Metaphors and the Aztec Mirror of Nature. In Signifying Animals: Human Meaning in the Natural World. Edited by R. G. Willis. London: Unwin Hyman, pp. 159-77.

Saunders, Nicholas J. 2001. A Dark Light: Reflections on Obsidian in Mesoamerica. World Archaeology 33: 220-36. [CrossRef]

Saunders, Nicholas J., and Elizabeth Baquedano. 2014. Introduction: Symbolizing Tezcatlipoca. In Tezcatlipoca: Trickster and Supreme Deity. Edited by Elizabeth Baquedano. Boulder: University Press of Colorado, pp. 1-6.

Schele, Linda, and David A. Freidel. 1990. A Forest of Kings: The Untold Story of the Ancient Maya. New York: Wm. Morrow \& Co., Inc.

Schele, Linda, and Mary Ellen Miller. 1986. The Blood of Kings: Dynasty and Ritual in Maya Art. Fort Worth: Kimball Art Museum.

Stone, Andrea J. 1991. Aspects of Impersonation in Classic Maya Art. In Sixth Palenque Round Table, 1986. Edited by Merl G. Robertson and Virginia M. Fields. Norman: University of Oklahoma Press, pp. 194-202.

Stone, Andrea J. 2014. Spiritual Journeys, Secular Guises: Rock Art and Elite Pilgrimage at Naj Tunich Cave. Mexicon 36: 49-64.

Stone, Rebecca. 2011. Jaguar Within: Shamanic Trance in Ancient Central and South American Art. Austin: University of Texas Press.

Stross, Brian. 1998. Seven Ingredients in Mesoamerican Ensoulment: Dedication and Termination in Tenejapa. In The Sowing and the Dawning: Termination, Dedication, and Transformation in the Archaeological Record of Mesoamerica. Edited by S. B. Mock. Albuquerque: University of New Mexico Press, pp. 31-39.

Stuart, David. 1987. Ten Phonetic Syllables. Research Reports on Ancient Maya Writing, 14. Washington, DC: Center for Maya Research.

Stuart, David. 1998. The "Fire Enters His House": Architecture and Ritual in Classic Maya Texts. In Function and Meaning in Classic Maya Architecture. Washington, DC: Dumbarton Oaks Research Library and Collection, pp. 373-426.

Stuart, David. 2005. Ideology and Classic Maya kingship. In A Catalyst for Ideas: Anthropological Archaeology and the Legacy of Douglas Schwartz. Edited by Vernon L. Scarborough. Santa Fe: School of American Research, pp. 257-85.

Stuart, David. 2021. The Wahys of Witchcraft: Sorcery and Political Power among the Classic Maya. In Sorcery in Mesoamerica. Edited by Jeremy D. Coltman and John M. D. Pohl. Boulder: University of Colorado Press, pp. 179-205.

Sugiyama, Nawa, Saburo Sugiyama, and Alejandro Sarabia. 2013. Inside the Sun Pyramid at Teotihuacan, Mexico: 2008-2011 Excavations and Preliminary Results. Latin American Antiquity 24: 403-32. [CrossRef]

Sugiyama, Saburo. 1992. Rulership, Warfare, and Human Sacrifice at the Ciudadela, Teotihuacan: An Iconographic Study of Feathered Serpent Representations. In Art, Ideology, and the City of Teotihuacan. Edited by J. C. Berlo. Washington, DC: Dumbarton Oaks Research Library and Collection, pp. 205-30.

Swenson, Edward. 2015. The Archaeology of Ritual. Annual Review of Anthropology 44: 329-45. [CrossRef]

Taube, Karl A. 1992. The Iconography of Mirrors at Teotihuacan. In Art, Polity, and the City of Teotihuacan. Edited by Janet C. Berlo. Washington DC: Dumbarton Oaks Research Library and Collection, pp. 169-204.

Taube, Karl A. 1994. The Birth Vase: Natal Imagery in Ancient Maya Myth and Ritual. In The Maya Vase Book, Vol. 4. Edited by Barbara Kerr and Justin Kerr. New York: Kerr Associates, pp. 650-85.

Taube, Karl A. 1996. The Olmec Maize God: The Face of Corn in Formative Mesoamerica. RES: Anthropology and Aesthetics 29/30: 39-81. [CrossRef]

Taube, Karl A. 2005. The Symbolism of Jade in Classic Maya Religion. Ancient Mesoamerica 16: 23-50. [CrossRef]

Taube, Karl A. 2016. Through a Glass Brightly: Recent Investigations Concerning Mirrors and Scrying in Ancient and Contemporary Mesoamerica. In Manufactured Light: Mirrors in the Mesoamerican Realm. Edited by Emiliano Gallaga and Marc G. Blainey. Boulder: University of Colorado, pp. 285-314.

Taube, Karl A., William A. Saturno, David Stuart, and Heather Hurst. 2010. The Murals of San Bartolo, El Petén. Part 2: The West Wall. Ancient America 10. Barnardsville: Boundary End Archaeology Research Center. 
Tate, Carolyn E. 1999. Patrons of Shamanic Power: La Venta's Supernatural Entities in Light of Mixe beliefs. Ancient Mesoamerica 10: 169-88. [CrossRef]

Tedlock, Barbara. 1982. Time and the Highland Maya. Revised edition. Albuquerque: University of New Mexico Press.

Tedlock, Dennis. 1985. Popol Vuh: The Mayan Book of the Dawn of Life, 1st ed. New York: Simon and Schuster.

Tedlock, Dennis. 2010. 2000 Years of Mayan Literature. Berkley: University of California Press.

Todd, Zoe. 2016. An Indigenous Feminist's Take on the Ontological Turn: 'Ontology' is Just Another Word for Colonialism. Journal of Historical Sociology 29: 4-22. [CrossRef]

Tylor, Edward B. 1958. Primitive Culture. 2 vols. Religion in Primitive Culture. New York: Harper and Row. First published 1871.

Vadala, Jeffrey. 2014. Cross-Culturally Exploring the Concept of Shamanism. HRAF. Available online: https://hraf.yale.edu/crossculturally-exploring-the-concept-of-shamanism/ (accessed on 22 February 2021).

Van Dyke, Ruth M. 2018. From Enchantment to Agencement: Archaeological Engagements with Pilgrimage. Journal of Social Archaeology 18: 348-59. [CrossRef]

VanPool, Christine S. 2003. The shaman-priest of the Casas Grandes region, Chihuahua. American Antiquity 14: 696-717. [CrossRef]

VanPool, Christine S. 2009. The Signs of the Sacred: Identifying Shamans Using Archaeological Evidence. Journal of Anthropological Archaeology 28: 177-90. [CrossRef]

VanPool, Christine S., and Todd L VanPool. 2007. Signs of the Casas Grandes Shamanism. Salt Lake City: University of Utah Press.

Vogt, Evon Z. 1966. H'iloletik: The Organization and Function of Shamanism in Zinacantan. In Summa Antropologica en Homenaje. Edited by Roberto J. Weitlaner. Mexico: INAH, pp. 359-69.

Vogt, Evon Z. 1976. Tortillas for the Gods: A Symbolic Analysis of Zinacanteco Rituals. Norman: University of Oklahoma Press.

Wallis, Robert J. 2009. Re-enchanting Rock Art Landscapes: Animic Ontologies, Non-Human Agency and Rhizomic Personhood. Time and Mind: The Journal of Archaeology, Consciousness and Culture 2: 47-70. [CrossRef]

Wallis, Robert J. 2013a. Exorcising 'spirits': Approaching 'Shamans' and Rock Art Animically. In Handbook of Contemporary Animism. Edited by Graham Harvey. Durham: Acumen, pp. 307-24.

Wallis, Robert J. 2013b. Animism and the Interpretation of Rock Art. The Journal of Archaeology, Consciousness and Culture 6: 21-28. [CrossRef]

Watanabe, John. 1992. Maya Saints and Souls in a Changing World. Austin: University of Texas Press.

Watkins, Joe. 2000. Indigenous Archaeology: American Indian Values and Scientific Practice. Walnut Creek CA: AltaMira Press.

Watts, Christopher, ed. 2013. Relational Archaeologies: Roots and Routes. In Relational Archaeologies: Humans, Animals, Things. New York: Routledge, pp. 1-20.

Weber, Max. 1969. Objectivity in Social Science and Social Polity. In Max Weber on the Methodology of the Social Sciences. Translated and Edited by Edward A. Shils, and Henry A. Finch. New York: Free Press.

Wilkinson, Darryl. 2017. Is There Such a Thing as Animism? Journal of the American Academy of Religion 85: 289-311. [CrossRef]

Zender, Marc. 2004. A Study of Classic Maya Priesthood. Unpublished doctoral dissertation. Department of Archaeology, University of Calgary, Calgary, AB, Canada. 